Dzieje Najnowsze, Rocznik LI - 2019, 4

PL ISSN 0419-8824

Przemysław Benken

https://orcid.org/0000-0002-1385-3016

Oddziałowe Biuro Badań Historycznych Instytutu Pamięci Narodowej w Szczecinie

\title{
„Burza nad Pekinem”. Przyczyny, przebieg i konsekwencje kryzysu w Chińskiej Republice Ludowej w 1989 r. w świetle archiwów Polskiej Rzeczypospolitej Ludowej
}

Abstrakt: Celem artykułu jest zaprezentowanie genezy, przebiegu i konsekwencji tzw. wydarzeń kwietniowo-czerwcowych w Pekinie w 1989 r. W tym roku Chińska Republika Ludowa przeżywała poważny kryzys wewnętrzny, którego rezultat stanowiły masowe protesty studenckie brutalnie stłumione przez wojsko. Kryzys zakończył się politycznym upadkiem sekretarza generalnego Komunistycznej Partii Chin Zhao Ziyanga, zastąpionego przez Jiang Zemina, który kontynuował tzw. politykę otwarcia i reform zgodnie z zasadami sformułowanymi przez Deng Xiaopinga.

Słowa kluczowe: Chińska Republika Ludowa, polityka „otwarcia”, kryzys 1989 roku, protesty studenckie, plac Tiananmen, masakra w Pekinie, Hu Yaobang, Deng Xiaoping, Zhao Ziyang, Jiang Zemin.

Abstract: The aim of the article is to present the genesis, progress and consequences of the so-called April-June Incidents of the 1989 in Beijing. The People's Republic of China experienced serious internal crisis that year resulting in massive students demonstrations brutally suppressed by army. The crisis ended up with the political downfall of the China Communist Party's General Secretary Zhao Ziyang replaced by Jiang Zemin who continued the so-called "policy of openness" and reforms on Deng Xiaoping's terms.

Key w or d s: People's Republic of China, “openness" policy, crisis of the 1989, student protests, Tiananmen Square, Tiananmen Square Massacre, Hu Yaobang, Deng Xiaoping, Zhao Ziyang, Jiang Zemin. 
Na przełomie lat siedemdziesiątych i osiemdziesiątych doszło do zasadniczych zmian koncepcji strategicznych Chińskiej Republiki Ludowej (ChRL) pod przywództwem Deng Xiaopinga, wymuszonych m.in. ciężką sytuacją państwa po okresie rządów Mao Zedonga. Zostały one oficjalnie zaprezentowane na III Plenum 11 kadencji Komunistycznej Partii Chin (KPCh) w grudniu 1978 r. i wynikały z planowanych reform mających na celu unowocześnienie ChRL, których nie można by prowadzić bez wsparcia z zagranicy, m.in. z Zachodu. Odpowiedzią na owe wyzwania była budowa tzw. socjalizmu o chińskiej specyfice w oparciu o politykę „otwarcia”, zakładająca m.in. odejście od retoryki konfrontacji i deklarowanie poparcia dla pokojowego współistnienia, dialogu oraz równych praw wszystkich uczestników stosunków międzynarodowych. Zamierzano w ten sposób zmienić negatywny wizerunek ChRL na świecie i stymulować wszechstronną współpracę gospodarczą Pekinu z zagranica. Jak celnie zauważono w notatce z lipca 1987 r., sporządzonej przez sekretarza Ambasady Polskiej Rzeczypospolitej Ludowej w Pekinie Krzysztofa Ciebienia, poważna zmiana koncepcji funkcjonowania ChRL, skutkująca polityka „otwarcia”, wiązała się z zakrojonym na dziesięciolecia programem reform i przyspieszonym rozwojem kraju, mającymi poprawić strategiczną pozycję Pekinu i umożliwić skuteczną obronę jego interesów.

Warunkiem sine qua non dla pomyślnej realizacji tego programu, który przekształcić ma Chiny w mocarstwo globalne o porównywalnym z ZSRR i USA potencjale gospodarczo-militarnym, jest „pokojowe otoczenie” i możliwości szerokiej współpracy gospodarczej, naukowo technicznej, technologicznej i wojskowej, bez której dokonanie wszechstronnej modernizacji kraju byłoby celem praktycznie nieosiagalnym ${ }^{1}$.

Zmiany wprowadzane w związku z polityka „otwarcia” uwidoczniły się w wewnętrznym funkcjonowaniu ChRL, przekładającym się też na ograniczona, aczkolwiek zauważalną w stosunku do czasów Mao Zedonga, liberalizację w sferze polityczno-społecznej². Najbardziej wyrazistym wskaźnikiem poziomu zmian zachodzących w Chinach było zmniejszenie się liczby więźniów.

${ }^{1}$ Archiwum Akt Nowych (dalej: AAN), Komitet Centralny Polskiej Zjednoczonej Partii Robotniczej (dalej: KC PZPR), Wydział Zagraniczny, LXXVI-714, Notatka pt. Dyskusje nad doktryną wojenną Chin w kontekście stanowiska ChRL w sprawie rozbrojenia sporządzona przez sekretarza ambasady PRL w Pekinie Krzysztofa Ciebienia, 11 VII 1987 r., k. nlb. Na temat ChRL w okresie przywództwa Deng Xiaopinga zob. np.: Ł. Gacek, Chińskie elity polityczne $w$ XX wieku, Kraków 2009, s. 253-269.

2 „Liberalizacja” na polu społeczno-politycznym w swych założeniach miała bardzo ograniczony zakres w stosunku do zmian zachodzacych na polu gospodarczym, by nie osłabiać dominującej roli KPCh w państwie. Jak stwierdził Deng Xiaoping w październiku 1978 r.: „Nie dopuścimy do tego, by narodziła się nowa burżuazja”. „Realizujmy politykę otwarcia na świat zewnętrzny i poznawajmy zdobycze naukowe i zaawansowane technologie innych krajów" (fragment rozmowy z delegacją dziennikarzy z Republiki Federalnej Niemiec), 10 X 1978 r., w: Koncepcje nauki, szkoty $i$ wychowania w ujęciu Deng Xiaopinga. Fragmenty przemówień z lat 1938-1992, wybór, tłum. i oprac. J. Marszałek-Kawa, Toruń 2013, s. 173. 
Jak podał Jakub Polit, spadła ona z $10 \mathrm{mln}$ w 1977 r. (1,05\% populacji) do $4-5,7$ mln w 1986 r. $(0,37-0,53 \%)^{3}$. Specyficznie rozumiana przez komunistów chińskich „demokratyzacja” życia (nie dość szeroka, by zadowolić osoby krytyczne wobec sytuacji w państwie i dążace do przyspieszenia procesu reform oraz nie dość wąska, by uniemożliwić dyskusję na trudne tematy) niewątpliwie legła u podstaw protestów z końca dekady lat osiemdziesiątych, aczkolwiek były one napędzane także przez szereg innych istotnych uwarunkowań.

Rozwój ChRL w pierwszej połowie lat osiemdziesiątych przebiegał tak dynamicznie, że stał się obiektem pogłębionych studiów w wielu państwach świata, zwłaszcza przeżywających poważne trudności gospodarcze (jak np. PRL). Badano czy, a jeśli tak, to w jakim stopniu, możliwe jest zaadaptowanie przez nie chińskich rozwiązań. Niemniej zbyt szybkie reformy w ChRL, po kilku latach sukcesów, zaczęły natrafiać na coraz większe trudności. Skutkowały one oznakami „przegrzania” gospodarki (mimo utrzymującego się wysokiego wskaźnika rocznego wzrostu PKB). Pojawiło się również wiele związanych z tym negatywnych zjawisk społecznych, a także dały o sobie znać nazbyt rozbudzone aspiracje ludności (dotyczące głównie poprawy warunków bytowych, aczkolwiek z czasem ujawniły się również oczekiwania o charakterze politycznym), których nadal nie potrafiono zaspokoić. Wszystko to generowało podziały w łonie kierownictwa partyjnego i rosnące niezadowolenie społeczne. To ostatnie przybrało poważne rozmiary, co uwidoczniło się w protestach, do których doszło pod koniec lat osiemdziesiątych, z punktem kulminacyjnym w postaci tzw. wydarzeń kwietniowo-czerwcowych w Pekinie w 1989 r., krwawo stłumionych przez wojsko.

Celem niniejszego artykułu jest zaprezentowanie genezy, przebiegu i następstw kryzysu w ChRL z 1989 r. Ponieważ sam przebieg pacyfikacji protestów w Pekinie w nocy z 3 na 4 czerwca został relatywnie dobrze opisany ${ }^{4}$ i łatwo można znaleźć szczegółowe informacje na jego temat, w tekście skupiono się w większym stopniu na wydarzeniach wcześniejszych, jak również na działaniach KPCh podejmowanych po zdławieniu „buntu”, dokonując także oceny ich skuteczności. Podstawową bazą źródłową dla artykułu stały się dokumenty zdeponowane w Archiwum Ministerstwa Spraw Zagranicznych (AMSZ) w Warszawie, których wartość w ocenie autora nie odbiega od materiałów anglojęzycznych, a pod pewnymi względami (m.in. ocena nastrojów społecznych w ChRL po 4 VI 1989 r.) nawet nad nimi góruje. Kwerendę pomocniczą przeprowadzono w Archiwum Akt Nowych i Archiwum Instytutu Pamięci Narodowej, aczkolwiek odnalezione tam materiały bardziej nadaja się do zrekonstruowania wpływu wydarzeń w ChRL na sytuację nad Wisła (polskie reakcje na protesty w Pekinie i ich brutalne stłumienie) i stosunek

\footnotetext{
${ }^{3}$ J. Polit, Chiny, Warszawa 2004, s. 308.

${ }^{4}$ Zob. m.in.: B. Góralczyk, Pekińska wiosna 1989. Poczatki ruchu demokratycznego $w$ Chinach, Warszawa 1999.
} 
KPCh do tzw. Okragłego Stołu i wyborów kontraktowych, co będzie przedmiotem osobnego studium. Ponadto, w celu ubogacenia i weryfikacji informacji zawartych w dokumentach AMSZ, sięgnięto m.in. po przetłumaczone na język angielski dokumenty udostępnione w ramach Wilson Center Digital Archive ${ }^{5}$ oraz wykorzystano wybraną polską i anglojęzyczną literaturę przedmiotu.

Mam nadzieję, że poprzez m.in. wprowadzenie do obiegu naukowego dokumentów z AMSZ (według mojej wiedzy dotąd niewykorzystanych) możliwe stanie się pełniejsze spojrzenie na opisywane wydarzenia, których waga była niezwykle duża dla rozwoju międzynarodowych stosunków politycznych i gospodarczych po $1989 \mathrm{r}$.

\section{Uwarunkowania}

Pierwsze poważniejsze oznaki kryzysu gospodarki ChRL były dostrzegane przez polskich dyplomatów w Pekinie przynajmniej od połowy lat osiemdziesiątych. Przykładowo w propozycjach do planu pracy Ambasady PRL w Pekinie na 1986 r., wysłanym do Warszawy 25 XI 1985 r., trafnie stwierdzano, że dalsze powodzenie chińskich reform uzależnione zostanie od opanowania postępującego wzrostu cen, przekładającego się na widoczne pogorszenie nastrojów obywateli: „Doświadczenia 1985 r. (inflacja, rosnące niezadowolenie ludności miejskiej) będą skłaniać władze do szczególnej ostrożności - w obawie przed społecznymi niepokojami" ${ }^{\text {. }}$

Komunistom nie udało się wszakże opanować sytuacji, a „przegrzana” w latach 1984-1985 gospodarka zaczęła powoli wymykać się spod kontroli ${ }^{7}$, przy czym materiał źródłowy wskazywał na fakt, iż w łonie kierownictwa

\footnotetext{
${ }^{5}$ Materiały dostępne na stronie internetowej: https://digitalarchive.wilsoncenter.org/collection/180/china-1989 (dostęp: 19 V 2019).

${ }^{6}$ Archiwum Ministerstwa Spraw Zagranicznych (dalej: AMSZ), Departament II, zbiór 22/89, wiązka II, teczka 5, Propozycja do planu pracy ambasady PRL w ChRL na 1986 r., 22 XI 1985 r., k. nlb.

7 Jeden z członków KC KPCh, Hu Qili, na początku kwietnia 1989 r. w rozmowie z redaktorem naczelnym gazety „Neues Deutschland”, opisał trudności ChRL następująco: „Największym problemem jest inflacja. W ubiegłych latach stopa inflacji przekroczyła 18 proc. W miastach osiagnęła nawet 20 proc. Oczywiście prowadziło to do całkiem silnych reakcji ludności, ponieważ ceny w Chinach przez długi czas były stabilne. Wynika to z dwóch powodów. Po pierwsze, mamy atmosferę oczekiwania przyspieszenia awansu społecznego. Ludzie chcieli wyjść ze stanu nędzy i domagali się rozwoju gospodarki tak szybko, jak to możliwe. Z pewnością było to szlachetne pragnienie, lecz konsekwencje tego były takie, że posunęliśmy się za daleko, konsumpcja wzrosła zbyt wysoko, tempo rozwoju było zbyt szybkie. [...] zaowocowało to deficytem surowców, energii i wielu innych rzeczy. Doprowadziło to do inflacji”. Wilson Center Digital Archive, Note about the meeting between the member of the Standing Committee of the Politburo of the Central Committee of the Chinese Communist Party, Hu Qili, with Herbert Naumann, Editor-in-chief of 'Neues Deutschland' in Beijing, 6 IV 1989 r. (dostęp: 14 V 2019).
} 
KPCh nie było jednomyślności na temat dalszego postępowania. Oprócz postulowanego przez osoby bardziej zachowawcze „działania na miarę sił”, duże wpływy miały koncepcje „liberałów”, zakładające przyspieszenie procesu reform - nie tylko ekonomicznych, lecz również politycznych i społecznych. $\mathrm{Ci}$ ostatni byli skupieni wokół sekretarza generalnego KPCh Hu Yaobanga postulującego „elastyczne podejście” do marksizmu i dokonywanie „doktrynalnych” przełomów, m.in. w naukach ekonomicznych. W maju $1986 \mathrm{r}$. polski dyplomata Jan Rowiński, podsumowujący rozmowy z przebywajacymi wówczas w Polsce przedstawicielami Chińskiego Instytutu Stosunków Międzynarodowych, pisał:

[Chińczycy] Starają się działać ostrożniej; rzeczywistość, szczególnie jeśli chodzi o reformy w gospodarce miejskiej, okazała się o wiele bardziej skomplikowana niż sądzili. Nie mają doświadczeń. Każde niepowodzenie powoduje wzrost sił przeciwnych reformie. Maja ogromne problemy natury teoretycznej i praktycznej. Na przykład: jaka jest granica reform, by nie doszło do naruszenia podstaw ustrojowych? Zastanawiali się i doszli do wniosku, że dotyczy to trzech głównych kwestii: nienaruszalności społecznej własności środków produkcji, utrzymania gospodarki planowej i przestrzegania zasady „każdemu według pracy”; wszystko inne może być reformowane ${ }^{8}$.

W raporcie politycznym Ambasady PRL w Pekinie za 1986 r. można było przeczytać, iż ostatnie miesiące upłynęły w związku z tym w ChRL (w której w grudniu doszło do pierwszych poważnych protestów studenckich) pod znakiem znacznie większego niż w latach poprzednich „fermentu” ideologicznego, politycznego i organizacyjnego'.

Zapoczątkowany pod koniec lat siedemdziesiątych dynamiczny rozwój ChRL napotykał w kolejnych latach dalsze trudności ${ }^{10}$, przez co niektóre grupy społeczne, których aspiracje zostały przez komunistów rozbudzone, nie mogły korzystać z niego w dostatecznym stopniu. Tymczasem Deng Xiaoping obiecywał przykładowo w marcu 1985 r. m.in.: „Celem walki, jaka prowadzimy przez ostatnich kilkadziesiąt lat, jest eliminacja ubóstwa. Po pierwsze, chcemy, by pod koniec obecnego wieku nasi obywatele prowadzili w miarę komfortowe życie. [...] Po drugie, w ciagu kolejnych trzech do pięciu dekad

8 AMSZ, Departament II, z. 22/89, w. III, t. 5a, Notatka z rozmów z członkami delegacji Chińskiego Instytutu Stosunków Międzynarodowych w czasie ich wizyty w Polsce w dn. 3-10 V 1986 r., 10 V 1986 r., k. nlb.

${ }_{9}$ Ibidem, w. IV, t. 5c, Raport polityczny ambasady PRL w Pekinie za 1986 r., grudzień 1986 r., k. nlb. Zwracano również uwagę na fakt, iż sekretarz generalny KPCh postulował w tym czasie walkę z tzw. sześcioma nieprawidłowościami w partii (m.in. wykorzystywanie władzy do czerpania osobistych korzyści, „biurokratyzm” i „liberalizm”), do których to aspektów nawiązano także w 1989 r., wskazując je jako jedne z ważniejszych przesłanek kryzysu.

10 AAN, KC PZPR, Wydział Zagraniczny, LXXVI-714, Wyniki gospodarcze ChRL osiagnięte w I półroczu 1987 r. oraz aktualne problemy rozwoju ekonomicznego ChRL, 11 VII 1987 r., k. nlb. 
pragniemy zbliżyć się do poziomu ekonomicznego krajów rozwiniętych, tak aby Chińczycy mogli uważać siebie za stosunkowo zamożnych" ${ }^{11}$.

Największe profity osiagały wciąż jednak osoby należące do nomenklatury partyjnej, które np. wykorzystując fakt wprowadzenia dwóch systemów cen na towary (kontrolowanego przez państwo i „wolnorynkowego”), używały swych wpływów, by tanio je kupować, po czym drożej sprzedawać. Chroniczny niedobór towarów w ChRL gwarantował osiaganie w ten sposób dużych zysków. Swoją rolę odgrywał również nepotyzm opisany przez jednego z amerykańskich dziennikarzy następująco: „Nawet jeśli nie pełnią wysokich urzędów, to i tak krewni chińskiej elity cieszą się przywilejami. Znani jako [...] «frakcja książąt», chodzą do najlepszych szkół, otrzymują najlepszą pracę, mieszkają w luksusowych mieszkaniach i mercedesami jeżdżą po zakupy do specjalnych sklepów"12.

Wywoływało to rosnace niezadowolenie społeczeństwa, którego wielu przedstawicieli uznawało, iż KPCh nie będzie zainteresowana usunięciem nękających ich problemów, gdyż jej prominenci straciliby wówczas możliwość czerpania dodatkowych korzyści. W raporcie politycznym Ambasady PRL w Pekinie za 1986 r. celnie stwierdzano: „Polityka wolnej konkurencji i zróżnicowanego wzrostu dobrobytu oraz przyspieszenia rozwoju zaczęła kształtować w społeczeństwie nowe podziały, pogłębiane dodatkowo na skutek korupcji, spekulacji, nepotyzmu. Inflacja, nierównomierny wzrost stopy życiowej, a nawet pogorszenie sytuacji materialnej niektórych grup [...] powodowały narastanie zwątpienia w trafność obranej drogi”13.

Największe rozczarowanie do kierownictwa KPCh wyrażała inteligencja, zwłaszcza studenci (aczkolwiek faktyczny wzrost cen detalicznych na poziomie $15 \%$ tylko w ciagu pierwszych dziewięciu miesięcy 1986 r. uderzał w całe społeczeństwo); według niektórych szacunków politykę państwa całkowicie popierało w tym okresie zaledwie $20-30 \%$ jej przedstawicieli. Było to związane z tym, iż formowanie się nowych elit (od 1978 r. zwiększono nabór na wyższe uczelnie) odbywało się pod wrażeniem warunków życia obserwowanych w krajach kapitalistycznych (poznanych m.in. dzięki polityce „otwarcia”), a lepszy dostęp do informacji o wydarzeniach na świecie ${ }^{14}$ skłaniał do refleksji, że

${ }^{11}$ „Celem reformy systemu zarządzania nauką i techniką jest uwolnienie sił produkcyjnych” (wystapienie na Narodowej Konferencji na temat Nauki i Techniki), 7 III 1985 r., w: Koncepcje nauki..., s. 191. Łukasz Gacek zauważył, że Deng Xiaoping reformując ChRL, czynił to pod hasłem bogacenia się. Ł. Gacek, op. cit., s. 263.

12 J. Greenwald, Za dużo wszystkiego $w$ rodzinie, „Time”, 5 VI 1989, w: Chiny rok po Tiananmen, Warszawa 1990, s. 23.

13 AMSZ, Departament II, z. 22/89, w. IV, t. 5c, Raport polityczny ambasady PRL w Pekinie za 1986 r., grudzień 1986 r., k. nlb. Zob. też: F. Deron, Chiny chore na reforme, „Le Monde”, 25-26 IV 1989, w: Chiny rok po Tiananmen..., s. 5-14.

${ }^{14}$ Przykładowo w 1985 r. w ChRL znajdowało się już ponad 40 mln telewizorów. E.F. Vogel, Deng Xiaoping and the Transformation of China, Cambridge-London 2011, s. 576. Populacja kraju liczyła wówczas 1,051 mld, co statystycznie dawało jeden telewizor na 26276 ludzi, niemniej w dużych miastach wartość tego wskaźnika była o wiele niższa aniżeli na wsi. 
ChRL reformuje się w tempie niedostatecznym. Wielu Chińczyków z uwaga śledziło efekty działań Michaiła Gorbaczowa w ZSRS, uznając je za właściwe. Dużą popularnością w ChRL cieszyły się również informacje na temat sytuacji w Polsce (dotyczące Niezależnego Samorządnego Związku Zawodowego „Solidarność” i Lecha Wałęsy) oraz na Węgrzech ${ }^{15}$.

Wprawdzie, jak już wspomniano, początkowo kluczową rolę w kształtowaniu postaw kontestacyjnych wobec polityki władz odgrywały zagadnienia o charakterze ekonomicznym, niemniej wkrótce miały do nich dołączyć żądania polityczne. W ocenie wielu Chińczyków tylko gruntowne zmiany na tym ostatnim polu mogły uczynić z ChRL państwo o ustroju zbliżonym do rozwiniętych krajów kapitalistycznych, co uznano za najlepszą gwarancje poprawy sytuacji gospodarczej. Aspekty ekonomiczny i polityczny tym samym nierozerwalnie się ze sobą splatały, co było dla KPCh bardzo niebezpieczne, gdyż prowadziło wprost do podważenia jej dominujacej roli w państwie.

Rezultat wspomnianych wyżej trudności stanowiły pierwsze masowe protesty studenckie z przełomu lat 1986-1987 (zapoczątkowane, jak już wspomniano, w grudniu 1986 r.), których najważniejszą konsekwencją okazała się wymuszona dymisja Hu Yaobanga z funkcji sekretarza generalnego KPCh w styczniu $1987 \mathrm{r}$. Niechętny jego nazbyt „liberalnej”16 i nazbyt samodzielnej polityce Deng Xiaoping doszedł do wniosku, że Hu Yaobang m.in. rozzuchwalił środowiska domagajace się „westernizacji” Chin, atakował partyjnych „konserwatystów", a popierane przez niego koncepcje przyspieszonego wzrostu gospodarki spowodowały, że wymknęła się ona spod kontroli. Ponadto $\mathrm{Hu}$ Yaobang okazał się zbyt „miękki” w trakcie rozwiązywania problemu demonstracji studenckich ${ }^{17}$. Wprawdzie nie były one tak liczne, jak w 1989 r., gdyż nie uzyskały poparcia wśród przedstawicieli innych grup społecznych (co miało

15 Miało to istotne przełożenie na późniejsze postulaty protestujących domagających się wprowadzenia systemu wielopartyjnego, wolnych wyborów i niezależnych związków zawodowych. Ponadto zachodni publicyści oceniali, iż Chińczycy, śledzący z dużą uwaga rozwój sytuacji w PRL korzystny dla NSZZ „Solidarność”, stawali się bardziej odważni w konfrontacji z własnymi władzami.

${ }^{16}$ Zob. AAN, KC PZPR, Wydział Zagraniczny, LXXVI-718, Hu Yaobang, „O wszechstronne zapoczątkowanie nowego kształtu modernizacji socjalistycznej” - referat wygłoszony na XII Zjeździe KPCh, 1 IX 1982 r., k. nlb.

${ }^{17} \mathrm{Hu}$ Yaobang w samokrytyce złożonej przed partyjnymi towarzyszami wyraził się na temat swych zaniechań w czasie protestów następująco: „Nie wierzyłem, że problem był tak poważny i uznawałem, że jeśli dobrze wykonywałem swoja pracę, to sam się rozwiąże”. Odnośnie do swej niewłaściwej postawy na polu ideologii Hu Yaobang stwierdzał: „Głównym powodem moich błędów jest to, że po Rewolucji Kulturalnej [...] chciałem zawsze stabilności i obawiałem się niepokoju. Skupiłem się na ograniczaniu «lewicowców», natomiast zbyt słabo ograniczałem "prawicowców». [...] Niektórym drugoplanowym kwestiom nadawałem zbyt wielkie znaczenie. [...] Gdy sprawowałem już urząd przez dłuższy czas, stałem się nadaktywny i porywczy. [...] Nie słuchałem spokojnie opinii innych osób”. Cyt. za: E.F. Vogel, op. cit., s. 581. Hu Yaobang pozostał wszakże członkiem Biura Politycznego Komitetu Centralnego KPCh. 
też dużą rolę $\mathrm{w}$ łatwiejszym i relatywnie szybkim ich stłumieniu), jednak stanowiły dla kierownictwa KPCh groźne ostrzeżenie przed „burżuazyjna rewolucją" i potraktowano je niezwykle poważnie.

Warto w tym miejscu odnotować zdecydowaną wypowiedź Deng Xiaopinga w trakcie lub tuż po zakończeniu protestów, będąca pewną wskazówką odnośnie do tego, jak kierownictwo partyjne zareaguje na wydarzenia z 1989 r.:

Deng powiedział, że władze polskie, wprowadzając w grudniu 1981 r. stan wojenny, przejawiły dalekowzroczność i bardzo mądre podejście wobec opozycji. Zastosowanie tej metody pozwoliło na opanowanie sytuacji. O środkach dyktatury nie należy tylko mówić; trzeba je czasami stosować. [...] opowiedział się za zastosowaniem w razie potrzeby podobnych środków dyktatury ludowej w Chinach. [...] Chiny będą uczyć się technologii od krajów zachodnich, w tym USA, i będą korzystać z zagranicznego kapitału, ale nie odejdą od ustroju socjalistycznego. [...] Przywódcy chińscy - wskazał - nie powinni przejmować się tym, jak ustosunkuje się do tej sprawy zagranica i jaki wpływ walka ta wywrze na wizerunek Chin poza ich granicami. Walka ta nie może zakończyć się porażką. Nie należy także obawiać się tego, co mówi zagranica, że „zadajemy cios własnemu wizerunkowi”. [...] Sytuacja wygląda zresztą tak, że zagranica pragnie stabilnej sytuacji w Chinach i nie troszczy się tak bardzo o prawa człowieka. W Chinach nie ma miejsca na liberalizację w duchu burżuazyjnym. [...] Deng zauważył, że podczas demonstracji trzeba było aresztować niewielką liczbę ich uczestników, aby uniknąć przelewu krwi. Jak można było inaczej postapić, skoro studenci wywoływali incydenty obliczone na spowodowanie przelewu krwi? ${ }^{18}$

Bezwzględna, lecz jednocześnie dobrze przemyślana postawa Deng Xiaopinga wobec wszelkich form oporu przeciwko władzy komunistycznej w Chinach, zademonstrowana w pełni w 1989 r., została poprzedzona próbami poprawy sytuacji w kraju. Służyć temu miał m.in. XIII Zjazd KPCh, w dniach 25 X - 2 XI 1987 r., poświęcony głównie problematyce związanej z zauważalnymi trudnościami powstałymi na skutek negatywnych rezultatów reform gospodarczych, które oddziaływały na społeczeństwo. XIII Zjazd odbył się pod hasłem reformy systemu cen i płac, jak również systemu zarządzania gospodarka, który zamierzano w większym niż dotychczas stopniu zdecentralizować i urynkowić. Zmianom tym miały towarzyszyć przyspieszone reformy polityczne, m.in. nakładające na struktury partyjne ograniczenia w zakresie administracji i zarządzania gospodarka, wprowadzające konsultacje społeczne, istotny wzrost znaczenia organów przedstawicielskich i organizacji polityczno-społecznych oraz „demokratyzację” życia społecznego. Co godne odnotowania, uznano, iż pomyślny proces reformowania gospodarki okaże się niezwykle trudny, jeśli nie uda się równocześnie dokonać implementacji zmian o charakterze politycznym ${ }^{19}$.

18 AMSZ, Departament II, z. 26/90, w. I, t. 5, Szyfrogram nr 336/I/571 z ambasady PRL w Pekinie (wraz z załącznikiem), 1 III 1987, k. 57-59.

19 Zob. AAN, KC PZPR, Wydział Zagraniczny, LXXVI-719, Zhao Ziyang, „Naprzód droga socjalizmu o chińskiej specyfice" - referat sprawozdawczy na XIII Zjeździe KPCh, 25 X 
Bardzo ważnym elementem XIII Zjazdu była decyzja Deng Xiaopinga o rezygnacji z większości sprawowanych funkcji, co stanowiło wstęp do wycofywania się z czynnego życia politycznego. Oznaczało to znaczny wzrost wpływów nowego sekretarza generalnego KPCh, Zhao Ziyanga (w latach 1980-1987 sprawował funkcję premiera i blisko współpracował z Hu Yaobangiem, co nie przeszkodziło mu później dołączyć do jego krytyków), typowanego na następcę Deng Xiaopinga, aczkolwiek ten ostatni zostawił sobie prawo do podejmowania decyzji w sytuacjach kryzysowych, przyjmujac funkcję nieformalnego najwyższego arbitra w przypadku sporów w łonie KPCh. Najważniejsza osobą w państwie faktycznie pozostawał więc mocno zaawansowany wiekowo (w 1987 r. liczył sobie 83 lata) Deng Xiaoping. Zhao Ziyang otrzymał relatywnie dużą swobodę $\mathrm{w}$ kreowaniu polityki ChRL, choć, jak pokazały wydarzenia w 1989 r., tylko do pewnego momentu.

Pomimo poważnych trudności przełomu lat 1986-1987 i odsunięciu $\mathrm{Hu}$ Yaobanga zdecydowano się na kontynuowanie reform, jednakże zamierzano się stanowczo przeciwstawić wszelkim formom „rewolucji burżuazyjnej”. Deng Xiaoping nie dokonał po zakończeniu protestów zasadniczej zmiany polityki ChRL na korzyść „konserwatystów” kosztem „liberałów”, podobnie jak zapoczątkowane na XIII Zjeździe ograniczanie aktywności Deng Xiaopinga oraz szeregu „starszych towarzyszy”, a także wyniesienie osoby byłego współpracowniku Hu Yaobanga na funkcję sekretarza generalnego nie oznaczały tryumfu zwolenników przyspieszenia reform. To co rzeczywiście miało wówczas miejsce, należałoby określić mianem klasycznego „cięcia po skrzydłach”. Lider chińskich komunistów przekonywał, że protesty „goniących za przywilejami” studentów (podburzonych przez niewielką grupę intelektualistów zajmujacych wysokie stanowiska w KPCh) zostały przez rząd opanowane „łatwo i szybko", a kwestię usunięcia Hu Yaobanga z funkcji sekretarza generalnego rozwiązano „bezboleśnie”, w związku z czym „pomimo tych wydarzeń, wszystko odbywać się będzie tak, jak zwykle i nie dojdzie do żadnych zmian" w polityce „otwarcia” ChRL ${ }^{20}$. Niemniej wyraźnie akcentował on konieczność walki z wszelkimi odstępstwami w sferze ideologii, przestrzegajacc, iż „gdyby Chiny zboczyły z obranej drogi powróciłyby do swojego pół-kolonialnego

1987 r., k. nlb. Według systematyki podanej np. przez Gacka w latach 1949-1978 można było mówić o funkcjonowaniu w ChRL gospodarki planowej, w latach 1978-1984 była to gospodarka planowa z nielicznymi elementami rynkowymi, w latach 1984-1987 wprowadzono gospodarkę towarową z elementami centralnego planowania, natomiast od 1988 r., po fiasku koncepcji firmowanych przez Zhao Ziyanga, przyjęto socjalistyczną gospodarkę towarowa, a od 1989 r. - po politycznym upadku sekretarza generalnego KPCh - działała w Państwie Środka do 1991 r. hybryda gospodarki planowej i rynkowej. Ł. Gacek, op. cit., s. 263.

20 „Musimy promować edukację w zakresie czterech podstawowych zasad oraz realizować politykę reformy i otwarcia na świat zewnętrzny" (fragment rozmowy z premierem Zimbabwe Robertem Mugabem), 20 I 1987, w: Koncepcje nauki..., s. 199. 
i pół-feudalnego statusu, a ich mieszkańców nie byłoby stać na żywność, ubrania, nie mówiąc już o bogaceniu się"21.

Jak pisał biograf Deng Xiaopinga, Ezra Vogel: „XIII Zjazd Partii uniknął ostrego rozłamu między konserwatystami, obawiającymi się zmian, a reformistami, którzy wyrażali strach przed stagnacja. Dwóch najbardziej kontrowersyjnych dygnitarzy, uchodzacych za reprezentantów opozycyjnych grup, sekretarz generalny $\mathrm{Hu}$ Yaobang i jego krytyk Deng Liqun, zostało usuniętych, co ułatwiło centrystom budowę koalicji na rzecz kontynuowania reform rynkowych i skromnych zmian w systemie politycznym" ${ }^{22}$. Podobny manewr zastosowano w czerwcu 1989 r. w ramach rozliczeń osób odpowiedzialnych za kolejny kryzys.

\section{Droga do Tiananmen}

Rozwiązania przyjęte na XIII Zjeździe KPCh nie przyniosły przezwyciężenia wielu negatywnych trendów, obserwowanych we wcześniejszych latach, co tłumaczono później w charakterystyczny sposób, zdejmujący odpowiedzialność z kierownictwa partyjnego. Uznano, że źródło problemów stanowiły „utrzymujące się stare mechanizmy i nawyki oraz opór kadry przywiązanej do starych metod działania"23. Szczególnie nieudana była próba reformy systemu cen z początku 1988 r., zakończona paniką na rynku i znacznym wzrostem inflacji. Miało to natychmiastowe przełożenie na spadek wartości pensji robotników, a kroki zaradcze, podjęte przez władze, polegające głównie na cięciu kosztów w nierentownych przedsiębiorstwach państwowych, tylko pogorszyły nastroje społeczne, nie poprawiając sytuacji gospodarczej (rezygnacja z niektórych prowadzonych inwestycji natychmiast przełożyła się na wzrost bezrobocia). Doprowadziło to w konsekwencji do dalszego osłabienia ChRL, przejawiajacego się m.in. w pogłębianiu dysproporcji w rozwoju między poszczególnymi

${ }^{21}$ „Musimy opowiedzieć naszej młodzieży o historii Chin” (fragment rozmowy z prezydentem Gabonu El Hadj Omarem Bongo Ondimba), 18 II 1987, w: Koncepcje nauki..., s. 204.

22 E.F. Vogel, op. cit., s. 591.

${ }^{23}$ AMSZ, Departament II, z. 4/94, w. I, Wstępna ocena wydarzeń w Pekinie (kwiecień-czerwiec 1989) sporządzona przez ambasadora PRL w Pekinie Mariana Woźniaka, 26 VI 1989 r., k. nlb. Jak stwierdził w kwietniu 1989 r. Hi Qili: „[...] jesteśmy obecnie na etapie przechodzenia od starego systemu do nowego. Stary system, [...] system maksymalnego centralnego planowania został odrzucony, lecz nowy system, dajacy więcej uprawnień fabrykom i przedsiębiorstwom, by tworzyły socjalistycznie planowaną gospodarkę konsumencka, nie został jeszcze w pełni wprowadzony, ani udoskonalony. W zasadzie kontrolujemy obecnie 50 proc. produkcji, lecz drugiej połowy już nie. [...] Zaowocowało to pewnym chaosem w naszym życiu gospodarczym". Wilson Center Digital Archive, Note about the meeting between the member of the Standing Committee of the Politburo of the Central Committee of the Chinese Communist Party, Hu Qili, with Herbert Naumann, Editor-in-chief of 'Neues Deutschland' in Beijing, 6 IV 1989 r. (dostęp: 14 V 2019). 
regionami kraju i gałęziami gospodarki, utracie kontroli w skali makro, inflacji, wzroście cen oraz bezrobocia (w 1988 r. oficjalnie odnotowano $20 \mathrm{mln}$ osób pozostajacych bez pracy) ${ }^{24}$. Jeden z niemieckich dziennikarzy podsumował wspomniane problemy następująco: „Reformy Denga znalazły się w najcięższym kryzysie. Wszyscy odczuwali biedę. Wzrost gospodarczy wyniósł co prawda 11,2 proc., ale galopujacca inflacja znacznie obniżyła, zwłaszcza w miastach, poziom życia. $\mathrm{Z}$ powodów braku energii przez wiele dni nie pracowało wiele fabryk. Niektóre surowce i poszukiwane artykuły konsumpcyjne były dostępne tylko za łapówkę. Produkcja zbóż spadała od czterech lat" ${ }^{25}$. Konsekwencje tych faktów ponosił Zhao Ziyang, którego pozycja w kierownictwie KPCh uległa osłabieniu (praktycznie utracił wpływ na sprawy gospodarcze) m.in. na rzecz jego głównego rywala, „konserwatywnego” premiera Li Penga.

Wprawdzie ChRL dysponowała zwiększającą się wciąż ilością nowoczesnych środków produkcji, jednak przyjęte formy zarządzania gospodarką i państwem były „archaiczne”, co uniemożliwiało poszerzenie społecznej bazy rządzenia. Szczególnie mocno przejawiało się to w dalszym ignorowaniu aspiracji inteligencji będącej pod wrażeniem rozwoju Hongkongu, Tajwanu, Singapuru, Korei Południowej oraz Japonii, stawiającego pod znakiem zapytania efektywność chińskiego socjalizmu. Warto dodać, że symbolem protestów z 1986 r. stał się wybitny chiński uczony, astrofizyk o międzynarodowej renomie, prof. Fang Lizhi, który w swych charyzmatycznych przemówieniach nie wahał się twierdzić, jak np. 18 XI 1986 r. podczas wystapienia na szanghajskim Uniwersytecie Tongji, iż żaden kraj socjalistyczny nie odniósł sukcesu po 1945 r., a system polityczny ChRL jest nowoczesną formą feudalizmu ${ }^{26}$. To właśnie po jednym z jego kolejnych przemówien, które miało miejsce 4 XII 1986 r., rozpoczęły się protesty studenckie. Źródłem ich początkowo nie był Pekin, lecz Hefei, gdzie przemawiał Fang Lizhi, chociaż rozruchy wkrótce rozprzestrzeniły się na inne wielkie miasta i uczelnie, docierając m.in. do stolicy ChRL i Szanghaju.

Postulaty polityczne $\mathrm{w}$ znacznym stopniu wynikały z uwarunkowań ekonomicznych, a na tym ostatnim obszarze sytuacja inteligencji chińskiej nie uległa poprawie. Środowisko to musiało zadowalać się niedajacym mu większych podstaw do optymizmu tłumaczeniem sytuacji, podobnym do tego,

${ }^{24}$ AMSZ, Departament II, z. 4/94, w. I, Wstępna ocena wydarzeń w Pekinie (kwiecień-czerwiec 1989) sporządzona przez ambasadora PRL w Pekinie Mariana Woźniaka, 26 VI 1989 r., k. nlb. Jak pisał np. Barry Naughton: „Gdy protestujacy studenci domagali się szybszej liberalizacji socjalnej i politycznej, byli oni z sympatią słuchani w dzielnicach mieszkalnych Pekinu i gdzie indziej; niezadowolenie z sytuacji ekonomicznej napędzało reformę polityczna”. B. Naughton, The Impact of the Tiananmen Crisis on China's economic transition, w: The Impact of China's 1989 Tiananmen Massacre, red. J.P. Béja, New York 2011, s. 163.

${ }^{25}$ M. Nass, Hieroglify na murze, „Die Zeit”, 28 IV 1989, w: Chiny rok po Tiananmen..., s. 16-17.

${ }^{26}$ E.F. Vogel, op. cit., s. 577. Zob. też: E. Cheng, Standoff at Tiananmen, Highlands Ranch 2009, s. 33; J.H. Willbanks, Fang Lizhi's Expanding Universe, „The China Quarterly” 1990, nr 9 (123), s. 459-484. 
jakie jeden z członków KC KPCh i bliski współpracownik Deng Xiaopinga, Hu Qili przedstawił na początku kwietnia 1989 r. w rozmowie z redaktorem naczelnym gazety „Neues Deutschland”:

Celem reform jest rozwój społeczeństwa, więc konieczne jest uwzględnienie podstawowych interesów całej ludności. Oznacza to, że pewne postulaty indywidualnych osób lub grup nie moga być jeszcze w pełni realizowane. Trzeba się tutaj nawet wykazać pewną chęcią do poświęceń. Mówiąc innymi słowy: partykularne interesy muszą ustapić wielkim interesom, krótkoterminowe interesy muszą ustapić miejsca długoterminowym, interes jednostek powinien obecnie ustapić przed interesem całego społeczeństwa ${ }^{27}$.

Tymczasem u obywateli ChRL wyraźnie widoczne były wzrost nastrojów konsumpcyjnych i frustracja wynikająca z niemożności ich zaspokojenia, przy jednoczesnym obserwowaniu postępującego rozwarstwienia społecznego, które miało miejsce na skutek uprzywilejowania osób i środowisk związanych z władzami. Jak zauważył polski dyplomata i ówczesny doradca ministra spraw zagranicznych, Ksawery Burski: „W sumie z reform skorzystały górne warstwy nadmiernie rozbudowanego aparatu partyjno-administracyjnego i wojskowo-politycznego, a także chłopstwo. Natomiast skutki inflacji najbardziej dotknęły inteligencję, uczącą się młodzież, częściowo klasę robotniczą oraz generalnie oświatę, naukę, służbę zdrowia"28.

Rosnąca liczba mieszkańców ChRL, rozczarowanych niewielkimi zmianami na lepsze w życiu codziennym w wyniku reform lub wręcz pogorszeniem się ich warunków bytowych, oczekiwała od władz dużo więcej aniżeli tylko sloganów o konieczności poświęcania się dla dobra ogółu. W szczególnie ciężkiej sytuacji znajdowali się m.in. nauczyciele. W pierwszej połowie 1988 r. w jednym z regionów kraju miało odejść z pracy, z powodu niskich płac, aż 800 osób, w konsekwencji zamknięto ponad 100 szkół ${ }^{29}$. Zwracano uwagę na narastające przekonanie szerokich kręgów społecznych w ChRL, iż edukacja nie stanowi właściwej drogi do poprawy warunków życia i zapewnienia sobie dobrej przyszłości. W związku z tym wielu rodziców zaprzestało posyłania dzieci do szkoły, za dużo korzystniejsze uznając skierowanie ich do pracy zarobkowej ${ }^{30}$. Jak pisał radca Ambasady PRL w Pekinie Bogusław

${ }^{27}$ Wilson Center Digital Archive, Note about the meeting between the member of the Standing Committee of the Politburo of the Central Committee of the Chinese Communist Party, $\mathrm{Hu}$ Qili, with Herbert Naumann, Editor-in-chief of 'Neues Deutschland' in Beijing, 6 IV 1989 r. (dostęp: 14 V 2019).

28 AMSZ, Departament II, z. 4/94, w. I, Notatka informacyjna nt. kryzysu politycznego w Chinach opracowana przez Ksawerego Burskiego, 12 VI 1989 r., k. nlb.

${ }^{29}$ Ibidem, Notatka pt. „Problemy oświaty w ChRL na tle obrad Ogólnochińskiego Zgromadzenia Przedstawicieli Ludowych VII Kadencji” opracowana przez radcę ambasady PRL w Pekinie Bogusława Maciborskiego, 15 IV 1989 r., k. nlb.

${ }^{30}$ W 1989 r. w ChRL żyło, według oficjalnych danych, ok. $230 \mathrm{mln}$ analfabetów (ok. 5\% populacji). 
Maciborski, w notatce z kwietnia 1989 r. poświęconej problemom oświaty w ChRL: „Pozycja nauczyciela została sprowadzona do zera” ${ }^{31}$. Był to smutny rezultat rewolucyjnej polityki jeszcze z okresu rządów Mao Zedonga, gdyż osoby zajmujące się nauką tradycyjnie cieszyły się w Chinach olbrzymim autorytetem społeczeństwa i dopiero komuniści zmienili ten stan rzeczy. Co godne odnotowania, Deng Xiaoping zdawał sobie sprawę z tego stanu rzeczy i przynajmniej w sferze deklaracji obiecywał jego zmianę, jak np. w listopadzie 1988 r., gdy stwierdził m.in.: „Dowiedziałem się, że pewien stary profesor z Uniwersytetu Pekińskiego powiedział ostatnio: «Moja pensja wynosi tyle samo, co w pierwszych latach istnienia Republiki Ludowej. Biorac jednak pod uwagę tempo wzrostu cen, mój poziom życia uległ obniżeniu o około dwie trzecie». Niezależnie od tego z iloma trudnościami musimy się zmierzyć, musimy za wszelką cenę poprawić jakość życia nauczycieli”" ${ }^{32}$.

$\mathrm{Z}$ podobnymi problemami i dylematami zmagali się studenci wyższych uczelni. Wielu z nich rezygnowało z nauki, zdając sobie sprawę, że po jej ukończeniu będą mieli problemy ze znalezieniem zatrudnienia, które odpowiadałoby ich aspiracjom ${ }^{33}$. Dotyczyło to zwłaszcza osób kształcących się na kierunkach humanistycznych i nauk społecznych, o których rynek pracy nie zabiegał i którzy mogli otrzymać państwową posadę jedynie dzięki nepotyzmowi. Musiało to negatywnie wpływać na nastroje młodych ludzi, co znalazło potwierdzenie w oficjalnych informacjach. Przykładowo szacowano, że w latach 1986-1989 procentowa liczba młodzieży popierającej „kapitalistyczna” droga rozwoju ChRL wzrosła dwukrotnie (z 16,8\% do $34,5 \%$ badanych) ${ }^{34}$.

Dostępny materiał źródłowy wskazuje, że kierownictwo KPCh - a raczej istniejace $\mathrm{w}$ jego łonie frakcje - podchodziło do kwestii niezadowolenia $\mathrm{w}$ środowisku młodzieży dwutorowo. $\mathrm{Z}$ jednej strony było ono tolerowane, by instrumentalnie wykorzystać je jako wzmocnienie pozycji „sił proreformatorskich" w KC i wywierać w ten sposób wpływ na zwolenników spowolnienia procesu reform. Opcję taką reprezentowali m.in. Hu Yaobang i jego następca na stanowisku sekretarza generalnego KPCh, który jako jeden z czołowych „liberałów” ChRL kontynuował politykę przemian w duchu wolnorynkowym, nakreśloną na XIII Zjeździe. Nie zdołał on jednak ograniczyć negatywnych

31 AMSZ, Departament II, z. 4/94, w. I, Notatka pt. „Problemy oświaty w ChRL na tle obrad Ogólnochińskiego Zgromadzenia Przedstawicieli Ludowych VII Kadencji” opracowana przez radcę ambasady PRL w Pekinie Bogusława Maciborskiego, 15 IV 1989 r., k. nlb.

32 „Nauka i technika stanowią podstawową siłę produkcyjną” (fragment rozmów z prezydentem Czechosłowacji Gustavem Husakiem oraz uwagi poczynione po wysłuchaniu sprawozdania na temat wstępnego programu reformy cen i wynagrodzeń), 5 i 12 IX 1988, w: Koncepcje nauki..., s. 206-207.

${ }^{33}$ Absolwenci byli kierowani do miejsc zatrudnienia wybranych przez państwo.

${ }^{34}$ AMSZ, Departament II, z. 4/94, w. I, Notatka pt. „Sytuacja w szkolnictwie wyższym ChRL po wydarzeniach czerwcowych" opracowana przez radcę ambasady PRL w Pekinie Bogusława Maciborskiego, 31 X 1985 r., k. nlb. 
zjawisk w gospodarce, w rezultacie czego znalazł się w trudniejszej sytuacji, aniżeli jego poprzednik, gdyż komuniści w 1989 r. musieli zmierzyć się już nie tylko z niezadowoleniem studentów, lecz także robotników, a nawet chłopów. Z drugiej strony „konserwatyści” krytykowali środowiska kontestujace politykę władz i domagające się „przywilejów”. Postawy te uznawano za negatywne rezultaty przejmowania prozachodniego stylu życia, a także nadmiernego pobudzenia „imaginacji” młodzieży usilnie dopominającej się, prócz poprawy warunków bytowych, o swobody obywatelskie, demokratyzacje życia i ograniczenie cenzury. Traktowano to jako realne zagrożenie dla KPCh i socjalizmu w Chinach, czyli wstęp do „rewolucji burżuazyjnej”.

Źródła wydarzeń z 1989 r. były zatem zróżnicowane i składały się na nie problemy ekonomiczne (negatywnie oddziałujące praktycznie niemal na cała ludność), dynamiczny rozwój sytuacji międzynarodowej pod koniec lat osiemdziesiątych i nabierajace tempa procesy globalizacyjne oraz zlekceważenie przez kierownictwo KPCh niezaspokojonych aspiracji społeczeństwa, zwłaszcza inteligencji, któremu nie zapewniono w ChRL warunków rozwoju na miarę jego rosnących oczekiwań. Swoją rolę odegrało też niewątpliwie ścieranie się w łonie KPCh frakcji „konserwatystów” i „liberałów”, przez co - w zależności od tego, która aktualnie zyskiwała przewagę - wysyłano do społeczeństwa sprzeczne sygnały. Bardzo ważna okazała się również śmierć Hu Yaobanga w kwietniu 1989 r., która - jak niżej opisano - dała społeczeństwu ChRL możliwość zademonstrowania swego niezadowolenia z polityki rządu. W mojej ocenie kluczowe było wszakże to, że wszystkie z powyższych elementów wystapiły w 1989 r. jednocześnie (można wręcz mówić o ich swoistej kumulacji).

\section{Śmierć Hu Yaobanga i początek protestu}

Zmarły 15 IV 1989 r. po ataku serca, do którego doszło siedem dni wcześniej podczas burzliwych obrad Biura Politycznego (BP) KPCh, Hu Yaobang uchodził w środowisku inteligencji chińskiej za „liberała”, który jako jeden z nielicznych rozumiał konieczność przyspieszenia procesu reformowania ChRL i poniósł tego konsekwencje. Jego odsunięcie od władzy na początku 1987 r. odbierano powszechnie jako niesprawiedliwość i zemstę „konserwatystów”, dlatego też były sekretarz generalny KPCh uznany został przez osoby kontestujące sytuację w państwie za „męczennika”. Nie dziwiło zatem, że na uroczystości żałobne w Pekinie stawiły się rzesze młodych ludzi, pragnące oddać mu hołd. Uczczenie pamięci Hu Yaobanga stało się przy tym pretekstem do wyrażenia niezadowolenia pod adresem władz. Jak stwierdził później Fang Lizhi: „Sam Hu Yaobang nie był aż tak bardzo ważny [...]. Jednakże w Chinach śmierć lidera służy jako wymówka dla ludzi, by mogli się zebrać. Partia nie może bowiem powiedzieć ludziom, by nie opłakiwali jej lidera! Ponieważ pogrzeb 
jest jedyną sytuacja, gdy ludzie mogą się zebrać, [więc] wykorzystujesz tę możliwość. Tylko gdy ludzie się zbiora, jest szansa, by coś osiagnąć” ${ }^{35}$.

Chociaż studenci początkowo nie artykułowali haseł politycznych, tylko okazywali smutek z powodu nieoczekiwanej śmierci Hu Yaobanga, będącej szokiem dla społeczeństwa, to jednak ich postawa ulegała szybkiej radykalizacji. Małe, spontaniczne i nieskoordynowane zgromadzenia studentów pod pomnikiem Bohaterów Ludowych na pl. Niebiańskiego Spokoju (Tiananmen) 15 kwietnia przekształcały się w coraz liczniejsze spotkania, na których dyskutowano również o bieżących problemach ChRL. 17 kwietnia tłum studentów był już tak duży, że policja zaczęła namawiać ich do rozejścia się, gdyż utrudniali funkcjonowanie położonych w pobliżu instytucji państwowych. W pekińskich kampusach pojawiły się plakaty apelujące o podjęcie „dziedzictwa" Hu Yaobanga i jego oficjalną rehabilitację, dotykające nadto takich zagadnień, jak wolność prasy, demokratyzacja i walka z korupcja ${ }^{36}$. Niepokojące z punktu widzenia komunistycznych przywódców ChRL musiały być transparenty z hasłami, jak np.: „Uczciwa i szczera osoba zmarła, a hipokryci i fałszywcy żyja sobie" ${ }^{37}$.

W nocy z 17 na 18 kwietnia na plac przybyło kilka tysięcy studentów, którzy zaczęli wysuwać postulaty polityczne pod adresem kierownictwa $\mathrm{KPCh}^{38}$. Podjęte 20 kwietnia próby oczyszczenia placu przez policję tylko pogorszyły sytuację, gdyż spowodowały włączenie się do protestów wielu studentów, którzy do tej pory nie byli w nie zaangażowani, lecz teraz chcieli wyrazić swój brak akceptacji dla brutalności władz ${ }^{39}$. Tego też dnia uaktywniła się grupa pekińskich robotników, która również wystapiła z postulatami wobec rządu. Szeregi protestujacych były ponadto sukcesywnie zasilane przez mieszkańców Pekinu i studentów przybywających do stolicy z innych ośrodków akademickich. Szacowano, że wieczorem 21 kwietnia na pl. Tiananmen zgromadziło się już 100 tys. osób, które odmówiły jego opuszczenia, łamiąc w ten sposób zarządzenie władz miejskich dążących do zamknięcia tej przestrzeni w związku z planowanymi na kolejny dzień uroczystościami pogrzebowymi $\mathrm{Hu}$ Yaobanga. Sam pogrzeb, transmitowany przez telewizję, wywołał emocjonalne reakcje zgromadzonych na placu tłumów. Kilku studentów zdołało

${ }^{35}$ Cyt. za: T. Brook, Quelling the People. The Military Suppression of the Beijing Democracy Movement, Stanford 1998, s. 22. Co godne uwagi, Hu Yaobang był opłakiwany także przez „konserwatystów” z KPCh, w tym jego wcześniejszych zagorzałych krytyków.

${ }^{36} \mathrm{O}$ dynamice protestów i celach stawianych sobie przez ich uczestników zob. np.: C.B. Francis, The Progress of Protest in China: The Spring of 1989, „Asian Survey” 1989, nr 9, s. 898-915.

37 Cyt. za: B. Góralczyk, op. cit., s. 119. Zdarzały się także sformułowania bardziej dosadne: „Ci, którzy powinni byli umrzeć - żyja; a ci, którzy powinni byli żyć - umarli”. Cyt. za: ibidem.

${ }^{38}$ Premier Li Peng oceniał, że protesty nabrały politycznego charakteru 18 IV $1989 \mathrm{r}$. E.F. Vogel, op. cit., s. 602.

3920 IV 1989 r. policja użyła pałek, w wyniku czego rany odniosło przynajmniej kilku studentów. B. Góralczyk, op. cit., s. 121-122. 
się wówczas przedostać przez kordon policji, by domagać się rozmowy z Li Pengiem, jednak żaden z liderów KPCh nie zamierzał wyjść do protestujących, co wywołało nastroje rozczarowania i niezadowolenia. 23 kwietnia utworzono Federację Autonomicznych Związków Studentów Uniwersytetów i Instytutów ${ }^{40}$, która wezwała studentów do bojkotu zajęć we wszystkich uczelniach stolicy.

Zhao Ziyang pod wrażeniem skali protestów zamierzał podjać dialog ze studentami, przy jednoczesnym zdecydowanym przeciwstawieniu się wszelkim formom rozruchów, które godziłyby w porządek publiczny. Li Peng oczekiwał wszakże od niego potępienia protestów i bardziej stanowczych działań, a nie mogac tego uzyskać, wykorzystał wyjazd sekretarza generalnego KPCh do Korei Północnej, by przekonać Deng Xiaopinga, iż dalsze zwlekanie może doprowadzić KPCh do jeszcze większego kryzysu. 26 kwietnia w kontrolowanej przez rząd prasie ukazał się tekst jednoznacznie wskazujący na to, że zgromadzenia studenckie stają się ruchem odśrodkowym przeciwko partii i rządowi, na który ten ostatni adekwatnie odpowie. Miała to być forma ostrzeżenia dla demonstrantów, niemniej Deng Xiaoping i Li Peng uzyskali efekty odwrotne do zamierzeń, gdyż doprowadzili jedynie do dalszej radykalizacji postaw demonstrantów i zwiększenia ich liczby ${ }^{41}$.

27 kwietnia ulicami Pekinu przeszedł kilkudziesięciotysięczny marsz studentów ze stolicy i innych miast, który w drodze na pl. Tiananmen pokonał bez większego trudu policyjne kordony i spotkał się z szerokim poparciem mieszkańców, a zwłaszcza robotników. By nie prowokować władz, organizatorzy pochodu zachęcali do skandowania patriotycznych haseł, jednakże 26 kwietnia ukazał komunistom siłę protestu, którego zasięg nie ograniczał się do jednej grupy społecznej, lecz - dzięki wysuwanym hasłom - zdobywał rzesze nowych zwolenników pobudzanych do aktywności brakiem jednoznacznego stosunku KPCh do demonstrantów. Nie powtórzyła się sytuacja z przełomu lat 1986-1987, gdy studenci byli rozgoryczeni brakiem zrozumienia ze strony społeczeństwa. Ich wzrastająca pewność siebie w kontekście konfrontacji z władzami w dużym stopniu wynikała także z tego, że uznawali się oni za elitę, której zadaniem jest pobudzenie całego narodu do działań w interesie Chin.

${ }^{40}$ W książce Bogdana Góralczyka struktura ta występowała pod nazwą Tymczasowej Federacji Studentów Wyższych Uczelni i Szkół Średnich Stolicy, a od 28 IV jako Autonomiczna Federacja Studentów Wyższych Uczelni i Szkół Średnich Stolicy. Ibidem, s. 130, 133. Jej przedstawiciele domagali się podjęcia z nimi dialogu przez władze, ukarania winnych pobicia studentów 20 kwietnia oraz obiektywnych relacji na temat protestu w chińskich środkach masowego przekazu.

${ }^{41}$ Ibidem, s. 128-129. Charakterystyczna była w tym kontekście odpowiedź do władz wystosowana przez młodych pracowników naukowych Uniwersytetu Pekińskiego: „My, intelektualiści i członkowie partii, gotowi jesteśmy raczej zginać, by uwolnić się w ten sposób od partii, która już całkowicie straciła poparcie narodu i jest kontrolowana przez garstkę bezdusznych osób”. Cyt. za: ibidem, s. 129. 
Gdy 30 kwietnia Zhao Ziyang powrócił do Pekinu, zdecydował się na złagodzenie oficjalnego kursu wobec protestujących, nakazując bardziej obiektywne przedstawianie demonstracji w środkach masowego przekazu, jak również sam wypowiedział się 3 i 4 maja w sposób bardzo koncyliacyjny ${ }^{42}$. Przyznawał, że niektóre postulaty studentów (m.in. dotyczące korupcji) były uzasadnione, a ich działanie miało swe źródła w patriotyzmie. Wprawdzie 4 maja $^{43}$ ulicami Pekinu ponownie przeszedł wielki marsz studentów, lecz wielu z nich było zadowolonych $\mathrm{z}$ nowego podejścia władz, reprezentowanego przez sekretarza generalnego KPCh, a większość stołecznych uczelni zapowiedziała zakończenie bojkotu i powrót do zajęć. W tym momencie wydawało się, iż sytuacja może zostać opanowana bez sięgnięcia po radykalne środki.

Liderzy protestów, obserwując postępującą demobilizację demonstrujących, odrzucili jednak propozycję podjęcia dialogu z władzami, uważając ją za element gry na czas ze strony komunistów. Jak pisał Bogdan Góralczyk: „Przywódcy studentów musieli szukać nowego źródła, by ponownie wzniecić masowy entuzjazm" ${ }^{4}$. Pojawiły się koncepcje bardziej konfrontacyjnego stanowiska wobec $\mathrm{KPCh}, \mathrm{z}$ protestem głodowym na czele ${ }^{45}$. Ten ostatni rozpoczał się 13 maja, dwa dni przed wizyta Michaiła Gorbaczowa w Pekinie. Ponieważ studenci zdawali sobie sprawę, że ceremonię powitalną przywódcy ZSRS zaplanowano na pl. Tiananmen i będzie ona transmitowana przed media krajowe i zagraniczne, zamierzali wykorzystać ten fakt do swoich celów. Deng Xiaoping chciał wprawdzie oczyścić plac z protestujących przed przybyciem Gorbaczowa, lecz Zhao Ziyang wolał rozpoczać negocjacje. Niezdecydowani jeszcze na rozwiazanie siłowe komuniści próbowali w ten sposób ratować resztki swego wizerunku.

Wieczorem 14 maja rozpoczęły się rozmowy między przedstawicielami KPCh i protestujących, zakończone niepowodzeniem. Sytuacji nie poprawiło formułowanie przez tych ostatnich coraz dalej idących żądań politycznych,

${ }^{42} \mathrm{~W}$ ocenie Polita Zhao Ziyang i osoby z jego otoczenia dawały protestujacym „przynajmniej bierne poparcie”, wykorzystując demonstracje do wewnętrznej rozgrywki o władzę w kierownictwie KPCh. Zob. J. Polit, op. cit., s. 312.

${ }^{43}$ Nawiązywano w ten sposób do idei ruchu 4 maja - chińskiego antyimperialistycznego, prodemokratycznego studenckiego ruchu politycznego opowiadającego się m.in. przeciwko postanowieniom traktatu wersalskiego, który przyznał położoną w prowincji Szantung bazę Jiaozhou Japonii walczącej podczas I wojny światowej po stronie Ententy. Nazwa ruchu wywodziła się od studenckich protestów, do których doszło na pl. Tiananmen 4 V 1919 r. Były one początkiem demonstracji, które rozlały się po całych Chinach, w rezultacie czego Państwo Środka m.in. odmówiło podpisania traktatu. Wydarzenia owe miały ogromne znaczenie dla rozwoju chińskiego ruchu narodowego i patriotycznego. Zob. np.: Ł. Gacek, op. cit., s. 74-75. Jeden z uczestników demonstracji z 1989 r. powiedział zachodnim dziennikarzom: „4 maja nie został jeszcze zakończony i to od nas zależy, czy zakończy się on sukcesem". Cyt. za: M. Nass, op. cit., s. 16-18.

${ }^{44}$ B. Góralczyk, op. cit., s. 139.

${ }^{45}$ D. Zhao, The Power of Tiananmen. State-Society Relations and the 1989 Beijing Student Movement, Chicago-London 2001, s. 160-162. 
jak m.in. odsunięcia od władzy Deng Xiaopinga (odegrał główną rolę w politycznym upadku Hu Yaobanga) i premiera Li Penga (,konserwatystę"), uznania przez rząd niezależnych organizacji studenckich oraz podjęcia przez kierownictwo partyjne dialogu z ich przedstawicielami przed kamerami i w obecności dziennikarzy zagranicznych. Ponadto oczekiwano znacznego przyspieszenia reform politycznych i gospodarczych oraz podjęcia skutecznej walki z korupcja. Rozmowy były również utrudnione przez fakt, że protestujący nie zorganizowali się odpowiednio i różne ich frakcje, niekiedy rywalizujące ze soba, przedstawiły swoje postulaty w nieskoordynowany sposób ${ }^{46}$.

\section{Wizyta Michaiła Gorbaczowa w Pekinie i eskalacja}

Radykalizacja młodzieży na ulicach Pekinu stała się najbardziej widoczna podczas wspomnianej już wizyty Gorbaczowa w ChRL w dniach 15-18 maja. Uczestniczący w niej asystent ministra spraw zagranicznych ZSRS Eduarda Szewardnadzego zapisał w dzienniku pod datą 15 maja, iż jadąca do Ogólnochińskiego Zgromadzenia Przedstawicieli Ludowych kolumna aut przewożących delegację musiała się ze względu na protesty poruszać inną niż zazwyczaj droga. W rezultacie nie dotarła pod zablokowane główne wejście do budynku (od strony pl. Tiananmen), lecz zajechała pod tylne. Delegacja z Moskwy mogła się wówczas zetknąć z takimi hasłami protestujących, jak np.: „ZSRS ma Gorbaczowa. A co my mamy?”; „Gorbaczow! Naród jest tutaj [na placu], nie tam [w siedzibie OZPL]!" ${ }^{47}$. Dwa dni później uczestniczący w wizycie Jewgienij Primakow miał ocenić sytuację w ChRL następująco: „To jest rewolucja. Ci, którzy przeżyli Rewolucję Kulturalna, mówią że nie pamiętają niczego podobnego" 48 . Ostatniego dnia wizyty Szewardnadze pisał m.in.: „Szanghaj, podobnie jak Pekin, jest w mocy protestujacych studentów. Jednakże tłumy na ulicach witają nas bardziej niż przyjacielsko" ${ }^{4}$.

Powyższe informacje znalazły potwierdzenie w cytowanej wyżej notatce ambasadora PRL w Pekinie Mariana Woźniaka: „Prowadzone na wielka skalę demonstracje nie pozwoliły wręcz na zrealizowanie niektórych punktów ustalonego programu wizyty. [...] Doszło do tego, że wielu dziennikarzy zagranicznych przestało zajmować się obsługą wizyty i szczytu, koncentrując swą uwagę na wydarzeniach na placu Tiananmen"50. Chociaż przyjazd

\footnotetext{
${ }^{46}$ J.P. Voiret, Watty fundament teoretyczny ruchu studenckiego $w$ Chinach, „Neue Zürcher Zeitung", 29 VII 1989, w: Chiny rok po Tiananmen..., s. 32-34.

47 Wilson Center Digital Archive, Diary of Teimuraz Stepanov-Mamaladze, 15 V 1989 r. (dostęp: 14 V 2019).

${ }^{48}$ Ibidem, 17 V 1989 r. (dostęp: 14 V 2019).

${ }^{49}$ Ibidem, 18 V 1989 r. (dostęp: 14 V 2019).

50 AMSZ, Departament II, z. 4/94, w. I, Wstępna ocena wydarzeń w Pekinie (kwiecień-czerwiec 1989) sporządzona przez ambasadora PRL w Pekinie Mariana Woźniaka, 26 VI 1989 r., k. nlb.
} 
Gorbaczowa nie miał nic wspólnego z demonstracjami i był zwieńczeniem długiego procesu normalizacji stosunków między ChRL a ZSRS, to ponieważ sowiecki przywódca uchodził za wzorowego „reformatora”, wyróżniającego się do tego młodym wiekiem wśród chińskich dygnitarzy (co nie pozostało niezauważone), jego obecność tylko dolała oliwy do ognia, upokarzając kierownictwo KPCh, niezdolne do zapewnienia spokoju w stolicy.

W drugiej dekadzie maja liczebność demonstrujących zbliżyła się do miliona (według niektórych szacunków nawet przekroczyła tę liczbę - m.in. podczas olbrzymiej demonstracji, która przeszła ulicami Pekinu 17 maja), przy czym nie byli to wyłącznie studenci i mieszkańcy stolicy, lecz również żołnierze, policjanci, przedstawiciele różnych organizacji państwowych, a nawet pracownicy aparatu partyjnego niższego szczebla ${ }^{51}$. Protesty objęły w tym czasie $\mathrm{w}$ sumie 80 miast i 600 uczelni $^{52}$, przy czym uczestniczyli w nich studenci z państw zachodnich (m.in. ze Stanów Zjednoczonych i Republiki Federalnej Niemiec), którym miało jakoby zależeć na zaognieniu sytuacji, by stworzyć w ten sposób warunki do przeprowadzenia „rewolucji burżuazyjnej”. Demonstranci mogli liczyć na poparcie transmitujących przebieg protestu mediów zagranicznych, których przedstawiciele pozostali w kraju po odlocie Michaiła Gorbaczowa do Moskwy, by śledzić dalszy rozwój sytuacji w Pekinie ${ }^{53}$.

W trafnej ocenie polskich dyplomatów kierownictwo KPCh, przynajmniej początkowo, szukało możliwości porozumienia się ze studentami, by uniknąć rozwiązania siłowego (nawet Deng Xiaoping do pogrzebu Hu Yaobanga podchodził do problemu relatywnie łagodnie). Sytuacja w drugiej połowie maja, po wizycie Gorbaczowa, była już zupełnie inna, a koncepcje Deng Xiaopinga i Zhao Ziyanga na temat sposobu zakończenia kryzysu ostatecznie się rozeszły ${ }^{54}$.

${ }^{51}$ Ibidem, Notatka informacyjna nt. kryzysu politycznego w Chinach opracowana przez Ksawerego Burskiego, 12 VI 1989 r., k. nlb.

52 Ibidem, Notatka pt. „Sytuacja w szkolnictwie wyższym ChRL po wydarzeniach czerwcowych” opracowana przez radcę ambasady PRL w Pekinie Bogusława Maciborskiego, 31 X 1989 r., k. nlb. W publikacjach zachodnich podaje się liczbę ok. 400 miast.

${ }^{53}$ Uznawano nawet, że żądanie demonstrantów, by Li Peng podał się do dymisji, wynikało z nacisków Zachodu, gdyż uchodził on za zwolennika zbliżenia z ZSRS.

${ }^{54}$ Warto odnotować informację podana przez Gorbaczowa w połowie lipca 1989 r., że podczas wizyty w Pekinie, na samym jej początku, jeszcze przed wspólną konferencja prasowa, Zhao Ziyang powiedział mu, że najważniejsza osoba w ChRL to Deng Xiaoping i wszystkie decyzje sa podejmowane przez niego. Gorbaczow odebrał to jako próbę wciagnięcia Deng Xiaopinga do współodpowiedzialności za powstanie kryzysu i wybór metody jego rozwiązywania, zaś swą rozmowę z nim wspomniał następująco: „W pewnym momencie podczas głównej konwersacji - z Deng Xiaopingiem - grupa studentów niemal przedostała się do budynku. Używano sloganów takich jak: «Gorbaczow, rozmawiasz z niewłaściwym człowiekiem»; «58-85» - nawiązanie do mojego wieku i wieku Deng Xiaopinga. Próbowaliśmy zachowywać się spokojnie i w sposób zrównoważony. Jednakże, szczerze mówiąc, myślałem, że powinniśmy wyjechać tak szybko, jak to tylko możliwe”. Wilson Center Digital Archive, Excerpts from the conversation between Mikhail Gorbachev and Rajiv Gandhi, 15 VII 1989 r. (dostęp: 19 V 2019). 
Mimo to nie rezygnowano jeszcze z negocjacji. Rozmowy z protestującymi w dniach 18-19 maja podjęli Zhao Ziyang i Li Peng. Szczególne wrażenie wywarło zwrócenie się przez tego pierwszego po południu 19 maja z niezwykle emocjonalnym apelem do głodujacych na pl. Tiananmen:

\begin{abstract}
Studenci, przybyliśmy zbyt późno. Jest nam przykro. [...] Obecnie najważniejszym jest, byście zakończyli ten protest. Wiem, że macie nadzieję, iż wasz protest głodowy spowoduje, że Partia i rząd udzieli wam satysfakcjonujacych odpowiedzi. [...] Czuję, że te problemy mogą zostać w przyszłości rozwiązane i możemy ostatecznie osiagnąc wspólne porozumienie. Musicie jednak widzieć, że sytuacja jest bardzo skomplikowana, to będzie długi proces. [...] Jesteście wciąż młodzi, my jesteśmy starymi ludźmi. [...] My jesteśmy starzy, my już się nie liczymy. [...] Studenci, wszyscy macie dobrą wolę i zależy wam na dobru naszej nacji, jednak jeśli ta sytuacja będzie trwać, wymknie się spod kontroli, powodując poważne konsekwencje [...]. Kończąc, mam tylko jedno życzenie. Jeśli zakończycie protest głodowy, rząd nie zatrzaśnie drzwi do dialogu, nigdy! 55
\end{abstract}

Było to ostatnie publiczne przemówienie Zhao Ziyanga, który w pełni zdawał sobie sprawę z faktu, że jego polityczny upadek został przesądzony na spotkaniu Komitetu Stałego BP KPCh 17 maja, na którym zapadły decyzje o siłowym zdławieniu protestów, czemu do końca się przeciwstawiał, po czym złożył dymisję. Zhao Ziyanga 28 maja umieszczono w areszcie domowym w Pekinie, w którym pozostał aż do śmierci 16 I 2005 r. ${ }^{56}$

\title{
Stan wyjątkowy
}

Rozmowy przedstawicieli kierownictwa KPCh z demonstrantami nie przyniosły efektów - komuniści, szykujący się do użycia wojska, nie zgodzili się na legalizację struktur powstałych w trakcie protestu, a studenci nie opuścili pl. Tiananmen. 20 maja ogłoszono wprowadzenie stanu wyjatkowego dla większości dzielnic Pekinu, co uzyskało pełną aprobatę Deng Xiaopinga uważającego, że wszelkie oznaki słabości na tym etapie sa nieakceptowalne. Usprawiedliwienie użycia armii stanowiło to, że studenci poparli „rewolucję burżuazyjna" ${ }^{57}$.

Nie spełniły się zatem oczekiwania kierownictwa KPCh na stopniowe uspokajanie nastrojów i rozładowanie emocji, aczkolwiek odkładanie w czasie użycie wojska miało też, według Polaków, wynikać m.in. z rozważania, czy

${ }^{55}$ Cyt. za: Culture and Politics in China. An Anatomy of Tiananmen Square, red. P. Li, M.H. Li, S. Mark, New Brunswick 1991, s. 123-123.

${ }^{56}$ Warto zauważyć, że Zhao Ziyang prowadził dziennik, który po jego śmierci przerzucono na Zachód i opublikowano. Zob. Prisoner of the State. The Secret Journal of Premier Zhao Ziyang, New York 2009.

${ }^{57}$ Zob. m.in.: A.P.L. Liu, Aspects of Beijing's Crisis Management: The Tiananmen Square Demonstration, „Asian Survey” 1989, nr 5, s. 505-521. 
gwałtowna reakcja władz nie doprowadzi do zaprzepaszczenia efektów polityki „otwarcia”, co utrudniłoby dalszy rozwój ChRL: „Wahano się z zastosowaniem rozwiązań siłowych, mając $\mathrm{w}$ pamięci m.in. międzynarodowe konsekwencje stanu wojennego w Polsce"58. Dyplomaci znad Wisły słusznie zauważali też, że przedłużający się okres wyczekiwania na podjęcie ostatecznych decyzji wskazywał na istniejące w łonie kierownictwa KPCh poważne rozbieżności na temat sposobu rozwiązania kryzysu. Była to kolejna odsłona bezwzględnej walki o wpływy między „konserwatystami” a „liberałami”, niemniej zwolennicy „twardego kursu”, w ocenie Polaków, poczuli się pewniej, gdy okazało się, że wprowadzenie stanu wyjątkowego uzyskało pełne poparcie władz prowincjonalnych, ministerstw, centralnych organów partyjnych oraz dowództwa armii. Oznaczało to, że w przypadku siłowego rozwiązania problemu państwu nie groził tak wielki chaos, a nawet paraliż, jak może niektórzy się obawiali ${ }^{59}$.

Ogromne znaczenie miało też jednoznaczne opowiedzenie się Deng Xiaopinga za zdecydowanym działaniem przeciwko protestujacym, z wykorzystaniem armii włącznie. Lider chińskich komunistów obawiał się, że dalsze tolerowanie sytuacji w Pekinie i innych miastach może wkrótce wymknać się spod kontroli i doprowadzić do szybkiej dekompozycji komunistycznego systemu władzy, co obserwowano w tym samym czasie w krajach Europy Środkowo-Wschodniej. Deng Xiaoping z niepokojem śledził postępująca radykalizacje haseł protestujących, które od ogólnych sloganów na temat „demokratyzacji” i „przestrzegania praworządności” przeszły do apeli o obalenie „skorumpowanego i zbiurokratyzowanego rządu", a także o odsunięcie na boczny tor jego samego, Li Penga oraz innych „weteranów” KPCh. Demonstranci nie tylko nie zamierzali ustępować, lecz eskalowali swoje żądania, domagając się faktycznie daleko idących zmian ustrojowych. Dla zwolenników „twardego kursu” była to „kontrrewolucja”, którą należało stłumić przy użyciu wszelkich niezbędnych środków, co wiązało się z koniecznością przerzucenia $\mathrm{w}$ rejon Pekinu znacznej liczby wojska.

O tym, jak bardzo poważna była sytuacja, świadczyły informacje zawarte w cytowanej już notatce Burskiego, mówiące, iż zarządzeń władz o stanie wyjątkowym nie przestrzegano $\mathrm{w}$ pełni, a koncentrujace się na przedmieściach stolicy ChRL oddziały wojska zatrzymywały się przy wzniesionych przez demonstrantów barykadach i „bratały się” z tymi ostatnimi ${ }^{60}$. Było to oznaka, że kryzys sięgał daleko głębiej, niż mogłoby się wydawać. Jak pisał ambasador PRL w Pekinie:

58 AMSZ, Departament II, z. 4/94, w. I, Notatka informacyjna nt. kryzysu politycznego w Chinach opracowana przez Ksawerego Burskiego, 12 VI 1989 r., k. nlb.

${ }_{59}$ Polit pisał, że protesty uzyskały poparcie ludności jedynie w miastach, natomiast poza nimi okazały się one niewielkie. Ponadto demonstranci, a także Zhao Ziyang i jego partyjni towarzysze nie mieli wpływu na postawę armii. Zob. J. Polit, op. cit., s. 311-312.

${ }^{60}$ AMSZ, Departament II, z. 4/94, w. I, Notatka informacyjna nt. kryzysu politycznego w Chinach opracowana przez Ksawerego Burskiego, 12 VI 1989 r., k. nlb. 
W ruchu aktywnie uczestniczyła znaczna część wykształconej młodzieży, część młodzieży robotniczej, a nawet chłopskiej; zyskał[a] ona także, zwłaszcza w fazie początkowej, ogromną sympatię i szerokie poparcie społeczeństwa Pekinu i innych dużych ośrodków miejskich. Była to już diametralnie jakościowo różna sytuacja od tej, jaka zaistniała w czasie ruchu studenckiego przełomu lat 1986-1987, który ograniczył się tylko do środowiska studenckiego i części kadry naukowo dydaktycznej ${ }^{61}$.

Jak podał Jakub Polit, z przeprowadzonego sondażu wynikało, że protest popierało aż $75 \%$ mieszkańców Pekinu ${ }^{62}$.

24 maja zgromadzone na przedmieściach Pekinu wojsko, które na skutek działań demonstrantów i ich sympatyków (m.in. otaczanie pojazdów przez tłumy ludzi) nie było w stanie przedostać się do centrum stolicy po ogłoszeniu stanu wyjątkowego, wycofało się z miasta w celu przegrupowania. Protestujaccy uznali za to punkt zwrotny. Ten ostatni miał wszakże dopiero nadejść w postaci krwawych wydarzeń w pierwszych dniach kolejnego miesiąca.

Obecnie wielu badaczy ocenia decyzję o kontynuowaniu demonstracji jako błędna. Przykładowo Polit pisał, iż „z dzisiejszej perspektywy, jak się wydaje niesłusznie - odmówili zaprzestania protestu"63. Interesujące podejście zaprezentował natomiast Krzysztof Gawlikowski, stwierdzając m.in.:

Patrząc z tej perspektywy pojawiają się rozmaite znaki zapytania co do działań „radykałów” na placu. Podejmowali oni wręcz desperackie wysiłki, by nie dopuścić do rozejścia się studentów i przedłużyć, choćby jeszcze o kilka dni, kończący się protest, mówiąc brutalnie - by dać możliwość i uzasadnienie przygotowywanej interwencji armii. Gdyby studenci rozeszli się „za wcześnie” dywizje wspierające „twardogłowych” nie miałyby okazji do takiego pokazu siły i późniejszych czystek „reformatorów” w aparacie partii i państwa. Czy wszyscy z owych „radykałów” działali tylko z czystej naiwności? Rozmaici wysłannicy błagali wręcz studentów, by się rozeszli i tłumaczyli, do czego ich działania prowadzą. Wiadomo dobrze, że ruchy opozycyjne i radykalne są zazwyczaj infiltrowane przez służby specjalne. Czy plac Tian'anmen nie był wyjatkiem? Czy nie jest to też kluczem do tak zadziwiajacego ukrywania się aż tylu przywódców ruchu i ich udanych ucieczek zagranicę? Przecież specjaliści z odpowiednich służb wiedzieli, że będą potrzebowali swoich tajnych współpracowników także w środowiskach emigracji politycznej. Niekoniecznie więc wszyscy aktywiści studenci kierowali się tylko wzniosłymi motywami ${ }^{64}$.

Według Gawlikowskiego istniała możliwość, iż przynajmniej pewna część przywódców protestów, jako agentura władz, dążyła do przedłużenia protestów. Celem tego było umożliwienie interwencji wojska i rozwiązania

${ }^{61}$ Ibidem, Wstępna ocena wydarzeń w Pekinie (kwiecień-czerwiec 1989) sporządzona przez ambasadora PRL w Pekinie Mariana Woźniaka, 26 VI 1989 r., k. nlb.

62 J. Polit, op. cit., s. 312.

${ }^{63}$ Ibidem, s. 113.

${ }^{64}$ K. Gawlikowski, Bogdan Góralczyk, Pekińska wiosna 1989. Poczatki ruchu demokratycznego w Chinach, Warszawa 1999, Studio Wydawnicze Familia, ss. 261 [rec.], „Dzieje Najnowsze" 2000, nr 1, s. 253. 
sprawy w sposób daleko bardziej szybki i gruntowny aniżeli w toku trudnych i ciagnących się bez wyraźnych efektów negocjacji, które wprawdzie na dłuższą metę mogłyby doprowadzić do deeskalacji protestu poprzez wyczerpanie jego uczestników, pozostawiłyby jednak znaczny potencjał odśrodkowy, który mógłby się z czasem ponownie ujawnić w najmniej dogodnym momencie.

W mojej ocenie większe znaczenie dla czasu trwania protestu miały: korzystny dla demonstrantów ciąg wydarzeń, jak m.in. okres żałoby po śmierci $\mathrm{Hu}$ Yaobanga, jego pogrzeb i wizyta Gorbaczowa, gwarantujace odroczenie pacyfikacji przynajmniej do 19 maja; początkowe „odparcie” wojska przez ludność Pekinu; deklaracje poparcia płynące z zagranicy; dynamika międzynarodowych stosunków politycznych; przekonanie o tym, iż KPCh nie użyje armii do krwawego tłumienia protestu; poczucie siły i świadomość konieczności wywalczenia postulowanych zmian w trakcie protestu. Część przywódców protestów oceniała ponadto, iż jeśli władze zdecydują się na rozwiązanie siłowe, fakt ten stanie się wielkim impulsem mobilizującym ludność do antyrządowych wystapień w całym kraju: „czekamy jedynie na rozlew krwi. Albowiem oczy narodu naprawdę się otworza, a my wreszcie się zjednoczymy dopiero wówczas, gdy rząd sięgnie dna zdeprawowania, spowoduje rzeź w naszych szeregach i utopi plac w morzu krwi”"65. Swą rolę w radykalizacji demonstracji i wydłużania czasu ich trwania odegrały także błędy władz, kilkukrotnie zaogniających sytuację, jak również obawy przynajmniej części kierownictwa KPCh przed międzynarodowymi implikacjami pacyfikacji, mogącymi wpłynąć na możliwości kontynuowania polityki „otwarcia”.

Osobnym wątkiem, wartym rozważania, jest koncepcja Gawlikowskiego mówiąca o tym, iż protesty zostały wykorzystane przez „konserwatystów” do wykonania swoistego zamachu stanu wymierzonego w Zhao Ziyanga:

Wojska wprowadzono na ulice stolicy, gdy ruch studencki już wygasał i nie służyło to realnej potrzebie „zaprowadzenia porządku w Pekinie”, ale stanowiło przede wszystkim pokaz siły dla całego kraju, a było też elementem swoistego zamachu stanu (w istocie nieudanego, gdyż konserwatystom nie udało się przejąć pełnej władzy). Wielka batalia polityczna toczyła się zatem w gabinetach władzy i na ich zapleczu, a studenci stali się tylko pionkami w tej grze ${ }^{66}$.

Moim zdaniem ruch studencki i jego postulaty z pewnością wpisały się $\mathrm{w}$ walki frakcyjne w łonie KPCh, lecz nie był on li tylko drugoplanowym ich aspektem. Dostępna dokumentacja archiwalna wskazuje, iż oceniano go jako bardzo duże zagrożenie dla reżymu KPCh, także w kontekście tego, co działo się w tym czasie w Europie Środkowo-Wschodniej. Być może zagrożenie, jakie on ze sobą niósł dla komunizmu w Chinach, zostało przez kierownictwo KPCh wyolbrzymione, niemniej dokumenty wskazuja, że było ono traktowane jako

${ }^{65}$ Cyt. za: B. Góralczyk, op. cit., s. 169.

${ }^{66}$ K. Gawlikowski, op. cit., s. 253. 
duże niebezpieczeństwo. Ponadto, nawet jeśli sam ruch studencki okazał się zbyt słaby na wymuszenie jakichkolwiek zmian w ChRL, należy pamiętać, iż miał on miejsce $\mathrm{w}$ okresie uchwyconego w materialne źródłowym widocznego wzrostu niezadowolenia dużej części społeczeństwa. To, że nawet połączenie protestów studenckich z ogólnym niezadowoleniem ludności nie mogło, jak pokazały wydarzenia, zagrozić supremacji KPCh, dało się z cała pewnościa stwierdzić dopiero z perspektywy czasu. Kierownictwo KPCh, działajace w trakcie kryzysu pod niezwykle silnym stresem, nie musiało postrzegać sytuacji tak realistycznie ani optymistycznie, jak późniejsi badacze. Opisując wypadki, nawiązywano wszak do ruchu 4 maja, rewolucji kulturalnej i kontrrewolucji. Wprawdzie za rozwiązaniem siłowym mocno opowiadali się zwolennicy frakcji „konserwatywnej”, niemniej ostateczne decyzje, po wysłuchaniu racji obu stron, podejmował Deng Xiaoping. Zacięta rywalizacja i walka o wpływy między „konserwatystami” a „liberałami” miała miejsce, jednakże wydaje się, iż należałoby ją postrzegać w odpowiednich dla jej znaczenia proporcjach. W mojej ocenie trzeba uznać, iż ruch studencki i jego siła, a także zaskakująco duże poparcie, jakie uzyskał od różnych grup społecznych, sprawiły, że stał się on ostatecznie nieakceptowalny, nawet jeśli niektóre osoby lub środowiska, także w łonie kierownictwa KPCh, dążyły, na różnych etapach i z różnych powodów, do tego, by nadać mu określony bieg.

\section{Pacyfikacja}

W nocy z 3 na 4 czerwca do Pekinu przybyły nowe oddziały sprowadzone z innych okręgów wojskowych, nie zaś te, które kierowano do stolicy ChRL od 20 maja. Jednostki te, używając broni pancernej, przystapiły do opanowania centrum Pekinu i likwidacji protestu. Operacja wojskowa trwała ponad dobę, przy czym z informacji zawartych w notatce przygotowanej przez Burskiego wiadomo, że część demonstrantów posiadała broń „uzyskaną prawdopodobnie wcześniej od żołnierzy lub zdobytą w walce" ${ }^{67}$. Polski dyplomata podsumowywał krwawą pacyfikację protestu następująco: „Po obu stronach są wielkie ilości zabitych i rannych szacowane na kilka tysięcy”68.

Wielkie straty osobowe niewątpliwie wynikały z faktu, iż pomimo wezwań ze strony władz do pozostania w domach, ogłaszanych przez telewizję wieczorem

${ }^{67}$ AMSZ, Departament II, z. 4/94, w. I, Wstępna ocena wydarzeń w Pekinie (kwiecień-czerwiec 1989) sporządzona przez ambasadora PRL w Pekinie Mariana Woźniaka, 26 VI 1989 r., k. nlb. Informacje o zdobytym na żołnierzach uzbrojeniu pojawiają się również w źródłach zachodnich, niemniej były to rzadkie przypadki i absolutnie nie można mówić o podjęciu przez protestujących równorzędnej walki z wojskiem.

${ }^{68}$ Ibidem. Straty po stronie wojska szacuje się różnie, najczęściej jednak wskazując na relatywnie niewielką liczbę od kilku do dwudziestu kilku zabitych. Rannych z pewnościa było znacznie więcej (kilkuset). 
3 czerwca, ludzie wciąż przebywali na ulicach, sądząc, że uda im się powtórzyć wcześniejszy scenariusz, gdy tłumnie otoczywszy pojazdy wojskowe, całkowicie uniemożliwili im poruszanie się w głąb miasta. Tym razem jednak żołnierze nie zamierzali ustępować, jak ich poprzednicy. Drogę wojsku wskazywały krążące nad miastem śmigłowce.

Pierwsze strzały padły o godz. 22.30. Początkowo żołnierze strzelali $\mathrm{w}$ powietrze, by oczyścić $\mathrm{w}$ ten sposób drogę z tłumów broniących dostępu do barykad na kluczowych skrzyżowaniach dróg prowadzących do pl. Tiananmen. Ponieważ nie przyniosło to efektu, wkrótce zaczęto strzelać do protestujących, którzy zostali tym faktem całkowicie zaskoczeni. Wymiana ognia, prowadzona głównie z broni automatycznej, była następnie kontynuowana przy kolejnych próbach powstrzymywania oddziałów wojska przed przemieszczaniem się $\mathrm{w}$ kierunku pl. Tiananmen, w wyniku czego straty wśród cywili zaczęły rosnaćc. Warto zauważyć, że - jak często bywa w takich sytuacjach - ginęli nie tylko protestujacy, lecz również przypadkowe osoby. Czołgi i transportery opancerzone rozbijały kolejne barykady, złożone m.in. z zakleszczonych pojazdów komunikacji miejskiej, bronione przez „ludzkie łańcuchy". Niektóre osoby podjęły próbę walki z żołnierzami, atakując ich kijami, kamieniami oraz rzucając $\mathrm{w}$ ich pojazdy pośpiesznie przygotowane, prymitywne „bomby” domowej produkcji (tzw. koktajle Mołotowa), co dało później władzom pretekst do twierdzenia, że otwierając ogień, armia działała w samoobronie ${ }^{69}$.

Gawlikowski, chyba nieco przesadnie, opisał starcia między wojskiem a ludnością Pekinu następująco:

[...] budowano barykady, urządzano prawdziwe polowania na patrole wojskowe, palono pojazdy wojskowe, niekiedy zdobywano nawet czołgi, rozbrajano żołnierzy, czasem ich wręcz linczowano, a ze zdobytych karabinów, i to maszynowych, robiono nieraz użytek. Tak więc setki ofiar padały z obydwu stron. Przedstawianie tych tragicznych wydarzeń, jako rozgrywających się wyłącznie na tym najsławniejszym placu Chin i to tylko jako rozstrzeliwanie tam, czy miażdżenie czołgami bezbronnych studentów, co robia czasem nasi publicyści, po prostu świadczy o nieznajomości podstawowych faktów ${ }^{70}$.

${ }^{69}$ Następca Zhao Ziyanga, Jiang Zemin, w rozmowie z członkiem BP KC Socjalistycznej Partii Jedności Niemiec, Günterem Schabowskim, odbytej w połowie lipca 1989 r., wypowiedział się w tej kwestii następująco: „Armia Ludowo-Wyzwoleńcza zgniotła armię Czang Kaj Szeka złożoną z ośmiu milionów ludzi. Ta armia nie poniosłaby ciężkich strat, które miały miejsce podczas rozruchów. Jednakże zaistniała nowa sytuacja - dobrzy i źli ludzie przemieszali się ze sobą. $\mathrm{Z}$ tego powodu żołnierze nie otrzymali rozkazu, by odpowiadać [na akty agresji]. Zrobili to dopiero w naprawdę ostatnim momencie, w samoobronie. W innym wypadku nie byłoby tak wielu ofiar wśród żołnierzy". Wilson Center Digital Archive, Letter to Erich Honecker from Schabowski on a meeting with Jiang Zemin, 14 VII 1989 r. (dostęp: 19 V 2019).

${ }^{70}$ K. Gawlikowski, op. cit., s. 248. 
Gdy wojsko nieuchronnie zbliżało się do pl. Tiananmen, znajdowało się wciąż na nim kilkadziesiąt tysięcy ludzi. Stopniowo docierały do nich informacje o masakrze na ulicach Pekinu, co, mimo pojawiania się różnych opinii, spowodowało decyzję o zaprzestaniu stawiania oporu wojsku. 4 czerwca o godz. 1.30 żołnierze zaczęli odcinać plac od reszty miasta, by uniemożliwić jakiekolwiek wsparcie dla zgromadzonych na nim demonstrantów. Działania te przyniosły kolejne ofiary śmiertelne, gdy za pomoca broni odparto tłumy próbujące dostać się na plac (w większości krewni protestujących). Niemniej, jak celnie zauważył m.in. Gawlikowski, na samym pl. Tiananmen nie doszło do rzezi, a studenci porozumieli się z wojskiem i opuścili plac przez specjalnie utworzony w tym celu korytarz w ugrupowaniu żołnierzy, chociaż nie obeszło się przy tym bez aktów przemocy. Ponadto kilkunastu studentów straciło życie, gdy w ich kolumnę maszerująca w kierunku kampusu wjechało nagle kilka czołgów.

To, iż na pl. Tiananmen nie doszło do masakry, tłumaczyć można na wiele sposobów. Interesująca konkluzję zaprezentował np. Gawlikowski, pisząc m.in.:

Z pewną dozą cynizmu dodać tė̇ trzeba, że nie było chyba całkowitym przypadkiem tak łagodne potraktowanie studentów i umożliwienie im spokojnego odejścia z placu. Rekrutowali się wszak oni w znacznej części z rodzin aparatu władzy, gdyż to jego potomstwo dostawało się bez trudu do elitarnych, pekińskich uczelni. Dlatego też i późniejsze represje dotknęły tylko nielicznych ich przywódców. Ofiary, i to tak liczne, padały natomiast na przedmieściach i na drodze do placu, gdzie z młodymi robotnikami i buntowniczymi przybyszami ze wsi, z „ludem chińskim” można się było liczyć znacznie mniej ${ }^{71}$.

Być może argument podniesiony przez Gawlikowskiego odgrywał pewna rolę, aczkolwiek trudno zgodzić się, by „konserwatywni” wojskowi prowadzący operację mieli jakieś szczególne względy dla protestujących, o których sam Deng Xiaoping myślał jako „niewdzięcznikach” korzystających dotąd $\mathrm{z}$ owoców jego reform ${ }^{72}$. Ponadto nie wydaje się, by demonstrujący na placu składali się głównie z dzieci pekińskiego aktywu partyjnego, gdyż dużą ich część, do tego najbardziej radykalna, stanowili w owym momencie studenci z innych ośrodków akademickich kraju. Wreszcie demonstranci, opowiadający się przeciwko nepotyzmowi i faworyzowaniu rodzin członków partii (krytykowano nawet synów Zhao Ziyanga za to, iż grywali oni w golfa), musieliby od początku występować sami przeciwko sobie. Argument Gawlikowskiego, podkreślajacego, podobnie jak robiono to w oficjalnych komunikatach władz ChRL, ograniczenie represji do wąskiej grupy przywódców studenckich, wydaje się problematyczny w świetle dostępnych źródeł, a jego uzasadnienie należałoby odrzucić.

\footnotetext{
${ }^{71}$ Ibidem, s. 254.

${ }^{72}$ E.F. Vogel, op. cit., s. 595.
} 
Fakt, iż do masakry na placu nie doszło, mógł wynikać z przynajmniej kilku elementów. Po pierwsze, ze znacznego zużycia sił i środków na samo przebicie się $\mathrm{w}$ rejon placu. Jak wiadomo, nieposiadajace specjalnego przygotowania do tłumienia demonstracji ulicznych wojsko napotkało na drogach i skrzyżowaniach prowadzących do pl. Tiananmen relatywnie silny opór ludności, który musiało przełamywać, ponosząc straty w zabitych i rannych, a także w sprzęcie. Biorac to pod uwagę, przystapienie z marszu do szturmu na plac, na którym zebrało się kilkadziesiąt tysięcy osób, byłoby zadaniem trudnym do wykonania nawet przez znaczne siły elitarnych i doskonale do tego celu przygotowanych jednostek. Dużo korzystniejszym rozwiąaniem wydało się z pewnościa doprowadzenie do tego, by protestujacy z własnej woli opuścili plac. Współgrało to także ze starożytnymi chińskimi doktrynami prowadzenia działań wojennych, doradzajacymi nie popychanie wroga do desperacji, np. poprzez odcięcie mu odwrotu, lecz pozostawienie mu możliwości ucieczki. Wreszcie wcześniejsze ofiary łatwiej było zatuszować, jak również dawały one możliwość przynajmniej częściowego puszczenia w ruch propagandy na temat „kryminalnych wydarzen”” towarzyszaccych tej pamiętnej nocy, aniżeli hekatomba na placu, która trudno by uzasadnić przed opinią międzynarodowa i własnym społeczeństwem.

\section{Liczba ofiar}

Liczba ofiar operacji wojskowej w nocy z 3 na 4 czerwca jest trudna do ustalenia. Oficjalnie określono ją na ok. 240-300 zabitych, w tym kilkudziesięciu studentów z Pekinu oraz niemal 30 żołnierzy; liczbę rannych szacowano zaś na ok. 6 tys. Niezależne od ChRL instytucje najczęściej podawały liczbę od kilkuset do kilku tysięcy zabitych, nie licząc rannych; według danych posiadanych przez ZSRS w październiku 1989 r. liczba ofiar sięgnęła 3 tys. ${ }^{73}$ $\mathrm{W}$ ostatnim czasie pojawiły się nowe informacje pozyskane $\mathrm{z}$ odtajnionego telegramu ambasadora Wielkiej Brytanii w Pekinie, Alana Donalda, z 5 VI 1989 r., który - powołując się na wysłannika wysoko postawionej osoby z chińskich kręgów władzy - pisał o tym, iż wojsko zabiło ponad 10 tys. ludzi ${ }^{74}$. Chociaż dyplomata uznawał te szacunki za wiarygodne, to jednak trudno je zweryfikować. O wiele łatwiej przyjać, że obejmują one nie tylko zabitych, lecz również rannych, co w mojej ocenie jest najbliższe prawdy. W cytowanym już dokumencie, sporządzonym 31 X 1989 r. przez radcę Ambasady PRL w Pekinie Maciborskiego, pisano, iż środowisko studenckie poniosło 4 czerwca znaczne straty: „Poza kilkudziesięcioma ofiarami śmiertelnymi były

\footnotetext{
${ }^{73}$ Wilson Center Digital Archive, Excerpt of a Politburo Meeting, 4 X 1989 r. (dostęp: 19 V 2019).

${ }^{74}$ Tiananmen Square protest death toll 'was 10,000', BBC News, 23 XII 2017.
} 
setki rannych. Całe natomiast środowisko przeżyło potężny szok psychiczny i dotychczas się z niego nie otrzasnęło"75. Maciborski dodawał, iż według dostępnych dla niego danych chińskich podczas pacyfikacji protestów poniosło śmierć 43 studentów pekińskich uczelni, jednakże nie ujawniono liczby ofiar spoza stolicy ChRL. W dokumencie trafnie podkreślono ponadto, że „nikt nie zginą na samym placu"76.

W ocenie Polita Deng Xiaoping miał nie wierzyć, iż interwencja wojska doprowadzi do masakry i jeszcze 9 czerwca nie znał jej prawdziwych rozmiarów ${ }^{77}$, co jednak zdaje się problematyczne, biorąc pod uwagę, iż wydał polecenie, by opanować sytuację w Pekinie przy użyciu wszelkich dostępnych środków. Krzysztof Łoziński uznał, natomiast, iż władzom chińskim zależało na jak największej liczbie ofiar, by sterroryzować w ten sposób społeczeństwo. Według tego publicysty gdyby protest przeciągną się jeszcze o kilka dni, jego rozczarowani uczestnicy zapewne sami by się rozeszli. Także decyzję o tym, by uderzyć na demonstrantów noca, tłumaczono nie tyle chęcia ograniczenia strat po stronie protestujących, co mniejszym oporem ${ }^{78}$. Łoziński, oceniający liczbę ofiar w Pekinie na 2 tys. zabitych i 5 tys. rannych, uważał, że o intencjach władz najlepiej świadczyła postawa żołnierzy podczas pacyfikacji: „Wszyscy moi rozmówcy mówili o nieprawdopodobnej brutalności sił rewolucyjnych. Wielokrotnie strzelano z broni maszynowej i dział czołgowych wprost w tłum bez żadnego wyraźnego powodu. Strzelano do uciekających i niebroniących się"79. Zdaniem Góralczyka „tej strasznej nocy z 3 na 4 czerwca 1989 roku, ludzie ginęli w Pekinie jak mrówki pod stopą słonia, koszono ich niczym świeży łan" ${ }^{80}$.

\section{Recepcja wydarzeń}

W ocenie polskich dyplomatów tak zdecydowane działania Chińczyków wynikały z rozłamu, jaki dokonał się na tle protestów w łonie KPCh. „Konserwatyści”, skupieni wokół Deng Xiaopinga, uznali, że doszło wówczas do próby kontrrewolucyjnego przewrotu, który groził restauracją systemu „burżuazyjnego”. Wprawdzie według późniejszych tłumaczeń Pekinu początkowo hasła ruchu studenckiego były zbieżne z celami KPCh (walka z korupcja, demoralizacja

\footnotetext{
${ }^{75}$ AMSZ, Departament II, z. 4/94, w. I, Notatka pt. „Sytuacja w szkolnictwie wyższym ChRL po wydarzeniach czerwcowych” opracowana przez radcę Ambasady PRL w Pekinie Bogusława Maciborskiego, 31 X 1989 r., k. nlb.

${ }^{76}$ Ibidem. W materiałach anglojęzycznych pojawiają się niekiedy informacje o trzech przypadkach mordów na pl. Tiananmen, niemniej trudno je zweryfikować.

77 J. Polit, op. cit., s. 314-315.

${ }^{78}$ K. Łoziński, Piekło Środka. Chiny a prawa człowieka, Warszawa 1996, s. 13-14.

${ }^{79}$ Ibidem, s. 12.

${ }^{80}$ B. Góralczyk, op. cit., s. 182.
} 
i nepotyzmem, demokratyzacja, przestrzeganie konstytucji i praworządności, konsekwencja we wprowadzaniu reform), niemniej demonstracje stopniowo przekształcały się w „rozruchy”, a w kulminacyjnym momencie przyjęły formę „kontrrewolucyjnego buntu”.

Komuniści chińscy starali się stworzyć wrażenie, że protestami kierowała niewielka grupa, która zamierzała wykorzystać naiwnych, patriotycznie nastawianych studentów do obalenia socjalizmu w ChRL. Osoby te miały być inspirowane przez Stany Zjednoczone (Centralna Agencję Wywiadowcza) ${ }^{81}$, Tajwan oraz środowiska wywodzące się z Hongkongu, które dostarczyły protestującym sprzęt radiofoniczny i nagłaśniający, a także poligraficzny (druk ulotek). Największe zastrzeżenia Pekin miał jednak do działań Waszyngtonu, który wtrącał się w sprawy wewnętrzne ChRL, zachęcając studentów do działań antyrządowych, a po pacyfikacji protestów nagłaśniał „rzeź” i groził sankcjami.

Dążąc do wytłumaczenia przebiegu wypadków społeczeństwu ChRL, a także opinii międzynarodowej, władze podzieliły liderów protestu na trzy kategorie „buntowników”. Do pierwszej zaliczono garstke ,zatwardziałych zwolenników burżuazyjnej i politycznych spiskowców”, druga tworzyli ludzie „powiąani z wrogimi ośrodkami zagranicznymi”, trzecią zaś stanowiły osoby „przekazujący najważniejsze tajemnice partyjno-państwowe nielegalnym organizacjom”. W podobny sposób pogrupowano także najbardziej aktywnych uczestników „rewolty”, dzieląc ich na: „wypuszczonych na wolność przestępców”, „członków grup chuligańskich o zabarwieniu politycznym” oraz „pozostałości po bandzie czworga i margines społeczny". Ponadto oficjalne czynniki chińskie zwracały dużą uwage na braki systemu penitencjarnego ChRL, przez co „wielu obecnych buntowników i bandytów już kilkakrotnie było aresztowanych, przebywało w więzieniach i mimo to nie zmieniło swego stosunku do socjalistycznej rzeczywistości”82. Charakterystyczne w tym kontekście, nie tylko dla KPCh, stało się wskazywanie na kryminalny charakter protestów

${ }^{81}$ AMSZ, Departament II, z. 4/94, w. I, Zapis wypowiedzi kierownika Wydziału Łączności Międzynarodowej, członka KC KPCh Zhu Lianga w czasie rozmów z delegacją KC PZPR w dn. 13 XII 1989 r., 15 XII 1989 r., k. nlb. Przykładem tego miał być fakt, iż Fang Lizhi po stłumieniu protestów znalazł, wraz z żona, schronienie w Ambasadzie Stanów Zjednoczonych w Pekinie, gdzie poprosił o azyl i po rocznym pobycie w placówce wyjechał do Ameryki. Ł. Gacek, op. cit., s. 272. Ponadto niektórzy uczestnicy demonstracji, którym udało się uniknąć aresztowań i wyjechać z ChRL, mieli opuścić kraj dzięki pomocy Centralnej Agencji Wywiadowczej. Według Jiang Zemina namioty na pl. Tiananmen, z których korzystali studenci, pochodziły z Hongkongu, a „Głos Ameryki” bezpośrednio łączył się z protestującymi co godzinę, zaś „organy” z Hongkongu - co pół godziny. Wilson Center Digital Archive, Letter to Erich Honecker from Schabowski on a meeting with Jiang Zemin, 14 VII 1989 r. (dostęp: 19 V 2019).

${ }^{82}$ AMSZ, Departament II, z. 4/94, w. I, Wstępna ocena wydarzeń w Pekinie (kwiecieńczerwiec 1989) sporządzona przez ambasadora PRL w Pekinie Mariana Woźniaka, 26 VI 1989 r., k. nlb. 
i rzekome zbrodnie dokonywane przez demonstrantów: „Wśród uczestników rozruchów znaczą część stanowił margines społeczny, m.in. byli kryminaliści [...] z natury rzeczy nienawidzący władzy i socjalizmu. To właśnie oni byli głównymi wykonawcami palenia, niszczenia i mordowania" $"$.

Działania władz komuniści starali się ukazać wyłącznie jako dążenie do „przywracania praworządności” zagrożonej przez protesty:

Na świecie nie ma takiego państwa, które tolerowałoby tak długo rozruchy, jakie miały miejsce w Pekinie w tym okresie. Pekin, a zwłaszcza plac Tiananmen, sa wielkim symbolem dla narodu chińskiego. Przez długi okres Tiananmen okupowany był przez uczestników rozruchów w liczbie od kilkunastu do kilkudziesięciu tysięcy osób dziennie. Jednocześnie demonstracje i pochody blokowały komunikację miejska. Życie centrum miasta na długi okres zostało sparaliżowane. Łącznie sytuacja taka trwała $48 \mathrm{dni}^{84}$.

Podkreślano również, iż pacyfikacja protestów zapobiegła jeszcze większej tragedii, jaka miałaby miejsce, gdyby cały kraj pogrążył się chaosie i odmętach „rewolucji burżuazyjnej”, a także, iż dzięki niej nastapiła szybka stabilizacja i normalizacja życia w Pekinie i kraju: „Cała partia i cały naród przystapiły do studiowania tez i ducha wystapień Deng Xiaopinga wygłoszonego na spotkaniu z wyższymi wojskowymi 9 czerwca [na którym polityk ten dziękował armii za dobrze przeprowadzoną operację] i «ujednolicenia poglądów» na jego gruncie" 85 .

Przyznawano, że pewna rolę w powstaniu kryzysu odegrały trudności gospodarcze ostatnich kilku lat, które przyczyniły się do „błędnego”

${ }^{83}$ Ibidem, Zapis wypowiedzi kierownika Wydziału Łączności Międzynarodowej, członka KC KPCh Zhu Lianga w czasie rozmów z delegacją KC PZPR w dn. 13 XII 1989 r., 15 XII 1989 r., k. nlb. Jiang Zemin w cytowanej już w jednym z powyższych przypisów rozmowie z przedstawicielem NRD powiedział, że otrzymał list od kanclerza RFN, Helmuta Kohla, który prosił go o łaskę w imieniu trzech „rebeliantów” skazanych na śmierć w Szanghaju: „Nazwał ich liderami studentów i reprezentantami ruchu demokratycznego. Jednakże byli oni wielokrotnie wcześniej skazywanymi chuliganami, którzy spalili pociag w mieście. Gdyby wiatr wiał [wtedy] w innym kierunku, fabryka chemiczna zostałaby zagrożona [pożarem]. Mogłoby to spowodować nieprzewidywalne konsekwencje dla Szanghaju”. Wilson Center Digital Archive, Letter to Erich Honecker from Schabowski on a meeting with Jiang Zemin, 14 VII 1989 r. (dostęp: 19 V 2019).

${ }^{84}$ AMSZ, Departament II, z. 4/94, w. I, Zapis wypowiedzi kierownika Wydziału Łączności Międzynarodowej, członka KC KPCh Zhu Lianga w czasie rozmów z delegacją KC PZPR w dn. 13 XII 1989 r., 15 XII 1989 r., k. nlb. Co godne odnotowania, podobny pogląd wyraził Henry Kissinger, stwierdzając, że żaden rząd na świecie nie pozwoliłby sobie na okupację przez osiem tygodni głównego placu w stolicy przez dziesiątki tysięcy demonstrantów zebranych przed głównym budynkiem rządowym. Zob. M. Grabowski, Wiek Pacyfiku - polityka Stanów Zjednoczonych wobec regionu Azji i Pacyfiku po roku 1989, Kraków 2012, s. 115.

85 AMSZ, Departament II, z. 4/94, w. I, Wstępna ocena wydarzeń w Pekinie (kwiecieńczerwiec 1989) sporządzona przez ambasadora PRL w Pekinie Mariana Woźniaka, 26 VI 1989 r., k. nlb. 
upowszechnienia w społeczeństwie tezy, że socjalizm się nie sprawdza i nie dorównuje kapitalizmowi. Często cytowano również stwierdzenie Deng Xiaopinga, mówiące o tym, że „Burza ta [protesty] wcześniej czy później musiała nadejść. Zdeterminowane to zostało ogólnym klimatem międzynarodowym i własnym lokalnym klimatem chińskim. Było to niezależne od woli ludzkiej" ${ }^{66}$. Zdejmowano w ten sposób zgrabnie odpowiedzialność za kryzys z kierownictwa KPCh, aczkolwiek w kontaktach na wyższym szczeblu Chińczycy dużą część winy zrzucali na „liberalna” politykę Zhao Ziyanga - m.in. za niedostateczne przeciwstawienie się „burżuazyjnej liberalizacji” przed kwietniem 1989 r. i błędy w koncepcjach wychowania ideowo-politycznego młodzieży. Przykładowo jego następca na stanowisku sekretarza generalnego KPCh, Jiang Zemin w rozmowie z członkiem BP KC Socjalistycznej Partii Jedności Niemiec, Günterem Schabowskim, odbytej w połowie lipca 1989 r., stwierdzał, że „rewolucja burżuazyjna” przez wiele lat rozprzestrzeniała się po Chinach, ponieważ wielu liderów KPCh, a głównie Zhao Ziyang, niedostatecznie się jej przeciwstawiało. Jak oceniał Jiang Zemin, idąc w ślady Deng Xiaopinga:

Rozruchy nie były niespodzianka, były widoczne na horyzoncie od dłuższego czasu. Gdyby partia miała dobra ocenę sytuacji i była zjednoczona, wypadki mogłyby się potoczyć znacznie jaśniej. Jednak Zhao Ziyang doprowadził do takiego rozwoju wydarzeń. Przez to i jego rozbijacką aktywność, został mocno skrytykowany. [...] Gdyby podjęto działania w myśl wstępniaka prasowego z 26 kwietnia, istniałaby możliwość szybszego i łatwiejszego rozwiązania. Jednakże, przez swoje wystapienie [...] 4 maja, Zhao Ziyang ponownie rozpalił ogień, który stał się już słabszy ${ }^{87}$.

Sytuację w partii „uporządkowano” w dniach 23-24 czerwca, kiedy to podczas IV Plenum KPCh 13 kadencji na sekretarza generalnego i członka Komitetu Stałego BP powołano Jiang Zemina, mającego „zaledwie” 62 lata. Wcześniej był on członkiem BP i I sekretarzem Komitetu Miejskiego KPCh w Szanghaju. Plenum zakończyło się po myśli grupy „konserwatywnej”, skupionej wówczas wokół Deng Xiaopinga, do której zaliczali się m.in. przewodniczący ChRL Yang Shangkun, Li Peng, sekretarz KC KPCh Qiao Shi, wicepremier Yao Yilin, minister obrony narodowej Qin Jiwei, szef Sztabu Generalnego Armii Ludowo-Wyzwoleńczej gen. Chi Haotian oraz minister bezpieczeństwa publicznego Wang Fang. Zwolennicy przyspieszenia reform gospodarczych i politycznych, którym przewodził Zhao Ziyang, utracili szereg stanowisk, a dążąc do „konsolidacji” szeregów KPCh, przystapiono do czystek w aparacie partyjnym, które dotknęły m.in. kierownictwa wyższych uczelni, aparat propagandy, środki masowego przekazu, sfere kultury oraz instytucje naukowo-badawcze zajmujące się naukami społecznymi i teoretycznymi,

\footnotetext{
${ }^{86}$ Cyt. za: ibidem.

${ }^{87}$ Wilson Center Digital Archive, Letter to Erich Honecker from Schabowski on a meeting with Jiang Zemin, 14 VII 1989 r. (dostęp: 19 V 2019).
} 
przy czym podstawowym kryterium oceny danej osoby stał się jej stosunek do wydarzeń kwietniowo-czerwcowych ${ }^{88}$.

„Pogrom” demonstrantów z początku czerwca 1989 r., chociaż niezmiernie kosztowny wizerunkowo i obarczony pewnym ryzykiem także w kontekście sytuacji wewnętrznej ChRL, która w przypadku niepowodzenia pacyfikacji protestów mogłaby się wymknać spod kontroli, przedstawiano jako sukces KPCh, który należało maksymalnie wykorzystać do osłabienia przeciwników politycznych w kraju i za granica. Wicedyrektor departamentu chińskiego MSZ, odpowiedzialnego za kontakty z ZSRS i krajami Europy Wschodniej, w rozmowie z ambasadorem PRL w Pekinie 12 VI 1989 r. powiedział m.in.:

Zdławienie buntu kontrrewolucyjnego jest wstępnym zwycięstwem, ale jeszcze nie całkowitym. Nadal mała garstka rozpowszechnia wrogie pogłoski, podjudza i próbuje nakłonić do działań przeciwko rządowi. [...] Garstka kontrrewolucjonistów projektowała nowy rząd. Sformułowała listę kadr i członków władz, które należy zlikwidować lub represjonować. Eskalacja następowała od ruchu studenckiego przechodząc do rozruchów i buntu. Część próbowała wedrzeć się do instytucji centralnych. W czasie zajść byli bici lub zabijani żołnierze i milicjanci. Palono pojazdy. [...] Było to wydarzenie negatywne, ale należy je tak spożytkować, aby wyszło na dobre. Wrogowie wykorzystali błędy naszej pracy. Wielu ludzi dało się oszukać ${ }^{89}$.

Odnosząc się do negatywnych międzynarodowych implikacji zajść w Pekinie, Chińczyk zwrócił uwagę ambasadora na fakt, iż cudzoziemcy nie rozumieja skomplikowanych spraw ChRL, przez co dokonuja przyspieszonych ocen i działań, jednakże KPCh nie dopuści do jakiejkolwiek ingerencji w swoje sprawy, ponieważ rząd jest silny i ma świadomość słuszności swoich działań. W grudniu $1989 \mathrm{r}$. bardzo podobnie wypowiedział się wicepremier ChRL i członek BP KPCh, Wu Xueqian, stwierdzajacc, że „Wiele emocji i kontrowersji wzbudziła sprawa stłumienia kontrrewolucyjnej rebelii w czerwcu br. Decyzja o rozwiązaniu siłowym została podjęta dopiero wtedy, gdy okazało się, że wykazana przez władze cierpliwość, wyrozumiałość, stosowanie środków perswazji, oraz próby dialogu nie dały rezultatu" ${ }^{\prime 0}$. Chińczyk chwalił się, że stłumienie „rebelii” zajęło „tylko kilka dni”.

Gdy wojsko „przywróciło porządek”, natychmiast przystapiono do skoordynowanych działań mających na celu eliminację resztek oporu społeczeństwa

${ }^{88}$ AMSZ, Departament II, z. 4/94, w. I, Notatka dotycząca oceny sytuacji w Chinach po IV Plenum KC KPCh, 26 VIII 1989 r., k. nlb. Jiang Zemin oficjalnie twierdził, że represje były skierowane w mała grupę „prawicowców”. Wilson Center Digital Archive, Letter to Erich Honecker from Schabowski on a meeting with Jiang Zemin, 14 VII 1989 r. (dostęp: 19 V 2019).

${ }^{89}$ AMSZ, Departament II, z. 4/94, w. I, Relacja ze spotkania ambasadora PRL w Pekinie Mariana Woźniaka z Bai Shuomianem (wicedyrektorem Departamentu ZSRS i Europy Wschodniej), 12 VI 1989 r., k. nlb.

${ }^{90}$ Ibidem, Zapis wypowiedzi członka BP KPCh Wu Xuegina na spotkaniu z członkami delegacji KC PZPR, 16 XII 1989 r., k. nlb. 
wobec polityki KPCh. Najsurowsze represje objęły liderów protestów, którzy nie zdołali uciec za granice - wielu skazano na kary śmierci lub osadzono w więzieniu. Pozostałym Chińczykom tłumaczono m.in., że sukces reform wiąże się z „koniecznością zaciskania pasa i uporczywej walki”, a w obliczu obecnych trudności niezbędne jest wychowanie narodu w duchu „wzmożonego wysiłku produkcyjnego i prostego życia”. Dla studentów przewidziano intensywne kilkutygodniowe szkolenia polityczne i tzw. wychowanie przez pracę, a nowy rektor Uniwersytetu Pekińskiego (jego poprzednik został odwołany) zadeklarował, iż „Nie ma miejsca na uczelni dla burżuazyjnej liberalizacji, ponieważ nie jest to problem akademicki, a polityczny"91. Ponadto, w ramach „dokręcania śruby” studentom, ograniczono nabór na niektóre kierunki (najbardziej ucierpiały nauki społeczne), przyjmując o 30 tys. osób mniej. Wprowadzono również ważne zmiany w systemie rekrutacji, które wymagały, by przed podjęciem studiów odbyć służbę wojskową lub posiadać odpowiedni staż pracy; dodatkowo osoba chcacca dostać się na studia II i III stopnia musiała, podobnie jak za czasów Mao Zedonga, legitymować się dwuletnim stażem pracy. Ambasada PRL w Pekinie informowała, że w ramach dodatkowych represji 730 studentów I roku stołecznego uniwersytetu skierowano na roczne szkolenie wojskowe do jednostki oddalonej o $260 \mathrm{~km}$ od stolicy, tworzacc z nich pięć kompanii męskich i dwie żeńskie. Znacząco ograniczono również możliwości wyjazdów zagranicznych, nastawiając się na szersze wykorzystanie profesorów wizytujacych. Przesunięto na inne stanowiska, zwolniono lub aresztowano członków kadry naukowej wspierajacych protesty ${ }^{92}$.

Komuniści prowadząc po 4 VI 1989 r. kolejną kampanię „antyburżuazyjną, odwoływali się do czterech pryncypiów polityki „otwarcia” (socjalistyczna droga rozwoju, dyktatura ludowodemokratyczna, kierownicza rola KPCh, uznanie myśli politycznej Mao Zedonga za zgodna z zasadami marksizmu-leninizmu), przeciwstawiajac je propozycjom ich oponentów, które „neguja najlepsze tradycje narodowe, propaguja nihilizm, dążą do westernizacji Chin, inaczej mówiąc, chcą wprowadzić w Chinach system kapitalistyczny"93. Podkreślano, że pluralizm, system wielopartyjny i demokracja parlamentarna, do której dążyli protestujacy, oznaczałyby faktyczne odsunięcie KPCh od władzy i upadek socjalizmu. Innym rezultatem byłoby powstanie nowej klasy społecznej, burżuazji, która resztę społeczeństwa wpędziłaby w biedę i nędzę. Wyrażano przekonanie, że gospodarka rynkowa zaowocuje jedynie chaosem, tymczasem „socjalistyczna cywilizacja duchowa” przyswaja „najlepsze osiagnięcia kultury

${ }^{91}$ Cyt. za: ibidem, Notatka pt. „Sytuacja w szkolnictwie wyższym ChRL po wydarzeniach czerwcowych” opracowana przez radcę ambasady PRL w Pekinie Bogusława Maciborskiego, 31 X 1989 r., k. nlb.

${ }^{92}$ Ibidem.

${ }^{93}$ Ibidem, Notatka dotycząca polemiki z opozycją chińską nt. realizowanej polityki reform i otwarcia na świat (na podstawie rozmów z zaprzyjaźnionymi Chińczykami i analizy prasy) sporządzona przez konsula PRL w Kantonie, 4 XI 1989 r., k. nlb. 
chińskiej i obcej”, dlatego też nie ma potrzeby zmiany tego podejścia: „Zdecydowanie odrzuca się duchowe śmieci z kultury feudalnej i kapitalistycznej [...]. KPCh realizuje reformy w oparciu o robotników, chłopów, inteligencję. Oponenci chcą realizować reformę przy pomocy wąskiej grupy "wybrańców» i stworzyć tzw. klasę średnia, która byłaby podstawową siłą w polityce dążacej do obalenia systemu socjalistycznego" ${ }^{94}$. Ważnym argumentem miało być również to, że „buntownicy” planowali wykorzystać etap reform w krajach socjalistycznych do swych celów poprzez ,pokojową rewolucję".

Z dokumentów polskiej dyplomacji wynikało, że obraz wydarzeń przedstawiany przez liderów KPCh odbierano w najlepszym przypadku z rezerwa nie tylko w większości państw świata, lecz także - co ważniejsze i szczególnie interesujące - nie zdołano do niego przekonać społeczeństwa ChRL. Jak stwierdzał wprost Maciborski:

Środowiska inteligencji akademickiej, a nawet szerzej, środowiska intelektualne, odebrały wydarzenia inaczej. Teza o kontrrewolucji nie spotkała się z jednoznacznym odbiorem i powszechną aprobata. Winą za tragiczny rozwój sytuacji obciąża się najwyższe kierownictwo i jego niezdolność do rozładowania sytuacji i zażegnania jej tragicznego końca. Nie daje się wiary twierdzeniu o nieuchronności tragedii. Część środowiska optuje za teza, iż tragiczne następstwa były skutkiem rozgrywek o władzę i zwycięstwa grupy konserwatywnej. Powszechne jest przygnębienie z powodu tragedii i jej konsekwencji politycznych i ideologicznych ${ }^{95}$.

Wbrew oficjalnym zapewnieniom płynącym z KPCh „jedność” społeczeństwa po czerwcu $1989 \mathrm{r}$. osiagano metodami zastraszania, nie na tyle jednak silnymi, by wyeliminować oznaki „ukrytego oporu” ludności i problemu „dwoistości poglądów" (inne deklarowano prywatnie, inne oficjalnie).

Wydaje się, że społeczeństwo chińskie, szczególnie w ośrodkach miejskich, gdzie „ruch [studencki]" rozwinął się na szeroką skalę, przeżywa okres frustracji i podziałów na tle stosunku do ostatnich wydarzeń, jak i metod zastosowanych do stłumienia „ruchu”. Wymuszana przez władzę w ramach trwającej kampanii unifikacja poglądów [...] nie znajduje potwierdzenia w „prywatnych” rozmowach z Chińczykami, traktujacymi „uczenie się przemówień Deng Xiaopinga” i innych programowych dokumentów jako zło konieczne, dające możliwość uniknięcia krytyki personalnej, posądzenia o sympatyzowanie z „kontrrewolucyjnym buntem” i różnorakich represji, z aresztowaniem włącznie. Jednocześnie odczuwalny jest pesymizm, co do pomyślnego kontynuowania reformy gospodarczej i niewiara w jakiekolwiek reformy polityczne oraz zwiększenie swobód demokratycznych. W tym kontekście „szeregowi” rozmówcy chińscy prezentuja żywy i pozytywny stosunek do przemian w ZSRR, Polsce i na Węgrzech ${ }^{96}$.

${ }_{94}$ Ibidem.

${ }_{95}$ Ibidem.

${ }^{96}$ Ibidem, Notatka dotycząca oceny sytuacji w Chinach po IV Plenum KC KPCh, 26 VIII 1989 r., k. nlb. Co ciekawe, Gawlikowski, powołując się na osobiste doświadczenia, przedstawił w 2000 r. obraz sytuacji całkowicie odmienny od informacji zawartych w dokumentach AMSZ, aczkolwiek odnoszący się do realiów obserwowanych w 1990 r.: „W Chinach [...] 
Przyczyn powyższego zjawiska upatrywano w braku konstruktywnego programu KPCh, który zyskałby poparcie społeczeństwa. Dobrym tego przykładem były nastroje w Szanghaju, gdzie z uwagi na silny atak miejscowych partyjnych „konserwatystów” na reformy obawiano się wręcz powrotu do metod rodem z czasów Mao Zedonga. Wprawdzie władze Szanghaju dystansowały się od skrajnych pomysłów oraz nie wdrażały zalecanych im czystek i weryfikacji kadry kierowniczej pod kątem wydarzeń kwietniowo-czerwcowych, jednak, jak pisał pod koniec września 1989 r. attaché konsularny Konsulatu Generalnego PRL w Szanghaju, Marek Frydrych: „Zaczęli się pojawiać weterani - emerytowani sekretarze i merowie oraz działacze aparatu partyjnego i administracyjnego, posiadajacy nadal rozległe wpływy. Uaktywniła się grupa w kierownictwie, która kariery swe rozpoczynała w okresie «Rewolucji Kulturalnej» (kadra szanghajska zawsze była posądzana o skłonności lewackie)" ${ }^{\prime 97}$. W ChRL obserwowano nadto powrót do bardziej scentralizowanych metod kierowania gospodarka. Uwidoczniło się to w spadku o 15\% liczby prywatnych przedsiębiorstw w pierwszym półroczu 1989 r. Oceniano, że dalsze reformy będa prowadzone $\mathrm{z}$ ostrożnością i po wykonaniu wielu eksperymentów ${ }^{98}$.

\section{Wychodzenie z kryzysu}

Dokonany jeszcze w czerwcu 1989 r. wybór Jiang Zemina, określanego mianem lidera „trzeciej generacji” KPCh, na nowego sekretarza generalnego okazał się bardzo znaczacy. Z jednej strony była to osoba lojalna wobec Deng

represje dotyczyły tylko nielicznych przywódców ruchu, a społeczeństwo wcale nie było zastraszone. Na jednej z uczelni pekińskich poproszono mnie wręcz (w 1990 r.) o wykład na temat «Solidarności» i przejęcia przez nią władzy w Polsce, a dyskusja po wykładzie, $\mathrm{z}$ otwartym wrażaniem sympatii dla «polskiej drogi» była niezmiernie ożywiona. Gdy znajomi widzieli mnie z oficjalna gazetą w ręce, z oburzeniem wręcz mówili: «jak możesz czytać tę gadzinówkę!». W skali masowej zaczęto wtedy słuchać radiostacji zachodnich, bynajmniej się z tym nie kryjąc”. K. Gawlikowski, op. cit., s. 251. Łoziński pisał, iż po pacyfikacji protestów aresztowano przynajmniej 500 osób, których losy udało się ustalić. Według Fang Lizhiego egzekucje osób zaangażowanych w protesty trwały jeszcze długo po ich stłumieniu i osiagnęły w skali kraju liczbę 20 tys. K. Łoziński, op. cit., s. 7-9. Przyjmując nawet ostatnią z podanych liczb jako zawyżona, trudno zgodzić się z tym, że represje (nie zawsze przecież oznaczające karę śmierci lub długoletnie więzienie) dotknęły jedynie nieliczne osoby. Nie chcąc dezawuować indywidualnych doświadczeń Gawlikowskiego z jego pobytu w ChRL, uważam, że nie należy ich traktować jako narzędzia oceny nastrojów społecznych w Państwie Środka po czerwcu 1989 r. Warto dodać, że stan wyjątkowy władze chińskie zniosły dopiero 10 I 1990 r.

${ }_{97}$ AMSZ, Departament II, z. 4/94, w. I, Ocena sytuacji polityczno-społecznej i gospodarczej przygotowana przez attaché konsularnego Konsulatu Generalnego PRL w Szanghaju Marka Frydrycha, 27 IX 1989 r., k. nlb.

${ }_{98}$ Ibidem, Notatka dotycząca oceny sytuacji w Chinach po IV Plenum KC KPCh, 26 VIII 1989 r., k. nlb. 
Xiaopinga i w pełni popierająca ostry kurs wobec wszelkich przejawów „rewolucji burżuazyjnej”, z drugiej jednak nowy sekretarz generalny należał już do kolejnego pokolenia przywódców ChRL, a do tego zdołał zaprowadzić porządek w Szanghaju w 1989 r. bez użycia wojska, nie był więc bezpośrednio obciążony krwią przelaną na pl. Tiananmen, co miało ogromne znaczenie w kontekście polityki wewnętrznej i zewnętrznej. Jak celnie zauważył Grzegorz Gołojuch: „Deng docenił fakt, że w Szanghaju stłumiono czerwcowe protesty względnie łagodnie (aresztowano tylko 150 osób, a trzech przywódców demonstrantów rozstrzelano), znajdując w Jiangu gospodarczego liberała, będącego zarazem politycznym konserwatysta" 99 .

O ile IV Plenum KPCh 13 kadencji umocniło pewne „konserwatywne” nurty w partii, to jednak Deng Xiaoping nie zamierzał dokonywać całkowitego odwrotu od przemian ChRL, które sam zapoczątkował 10 lat wcześniej. $\mathrm{Z}$ tego powodu dążył do zbudowania stabilnej ekipy rządowej, która skupiłaby się na rozwiązywaniu bieżących problemów i porzuciłaby personalne animozje. Powstałe w ten sposób jądro kierownicze miało odzyskać zaufanie społeczeństwa i kontynuować proces reform w taki sposób, by nie zagroziły już interesom KPCh.

W ocenie polskich dyplomatów rozwój sytuacji w ChRL w 1989 r. świadczył o nabierającym znaczenia konflikcie pokoleniowym w łonie KPCh i związanym z nim początku walk o sukcesję po Deng Xiaopingu. Za znaczacy uznano fakt, że do ścisłego kierownictwa partyjnego nie wprowadzono po 4 czerwca przedstawicieli armii i osób odpowiedzialnych za stan wyjątkowy w 1989 r. i późniejszą kampanię podziękowań dla wojska, co interpretowano jako sygnał, że Deng Xiaoping był świadom niepopularności sposobu, w jaki rozwiązano problem protestów społecznych, przejawiający się w niechęci, a nawet wrogości społeczeństwa wobec armii. Jednocześnie w górę partyjnej hierarchii szli ludzie z ośrodków, gdzie nie doszło do użycia wojska. Przeciwdziałano w ten sposób obniżaniu prestiżu KPCh i dobrego imienia partii w następstwie wydarzeń z czerwca 1989 r., dostrzegalnego przez ambasadora PRL w Pekinie: „Pogłębił się trudny do zniwelowania rozdźwięk między partią, a większościa inteligencji i młodzieży, zwłaszcza wykształconej. Nastapił znaczny wzrost frustracji społecznych i niewiary w oficjalnie głoszone hasła i autorytety"100.

Polscy dyplomaci celnie zauważali, że proces reform został wprawdzie w 1989 r. mocno zahamowany, jednak nie doszło do ich odrzucenia ani tym bardziej do prób powrotu do rozwiązań sprzed 1979 r. Prognozowano, że wraz z upływem czasu i ostatecznym odejściem wiekowych „konserwatystów”

${ }_{99}$ G. Gołojuch, Cztery pokolenia chińskich przywódców. Problemy lub przebieg instytucjonalizacji sukcesji władzy w Chińskiej Republice Ludowej, „Politeja” 2005, nr 1 (3), s. 334. Jiang Zemina określano niekiedy mianem „ekonomicznego centrysty”.

100 AMSZ, Departament II, z. 4/94, w. I, Wstępna ocena wydarzeń w Pekinie (kwiecieńczerwiec 1989) sporządzona przez ambasadora PRL w Pekinie Mariana Woźniaka, 26 VI 1989 r., k. nlb. 
w ChRL pojawia się sprzyjające warunki dla „reformatorów i zwolenników demokratyzacji” 101 . Jak pisał Burski: „Obecny kryzys polityczny w Chinach jest wynikiem błędów w sterowaniu reformami gospodarczymi, a głównie braku adekwatnych działań w reformowaniu życia społeczno-politycznego. Jest też wyrazem walki o władzę w kierownictwie i problemu zmiany pokoleń. W wyniku kryzysu tempo reform zostanie zwolnione, niemniej zasadnicza linia reform i otwarcia zostanie utrzymana" ${ }^{102}$.

Naczelnym wyzwaniem KPCh stało się zlikwidowanie skutków „fermentu w sferze politycznej, ideologicznej i świadomości społecznej”, co chciano osiagnąć poprzez szeroką kampanię ideologiczno-propagandową w celu „unifikacji” poglądów społeczeństwa z oficjalną wykładnią. Miało temu towarzyszyć zdecydowane zwalczanie korupcji, nepotyzmu i przestępczości gospodarczej (zwłaszcza wśród kadry kierowniczej wyższego szczebla), co częściowo wychodziło naprzeciw postulatom protestujących w $1989 \mathrm{r}$. Zamierzano też w ten sposób zabezpieczyć stabilny rozwój ekonomiczny ChRL.

\section{Stosunek zagranicy}

Należałoby zauważyć, że brutalne stłumienie protestów wywołało bardzo negatywną reakcję większości państw świata, ze szczególnym uwzględnieniem Zachodu, natomiast $\mathrm{w}$ krajach socjalistycznych dał się zauważyć pewien rozdźwięk w tej kwestii - Socjalistyczna Federacyjna Republika Jugosławii i Węgierska Republika Ludowa potępiły postępowanie Pekinu, NRD, Czechosłowacka Republika Socjalistyczna i Ludowa Republiki Bułgarii udzieliły mu poparcia, natomiast PRL i ZSRS „zajęły stanowisko bardziej wyważone, humanitarne [sic!]"103.

Chociaż wydawało się, że ChRL może w konsekwencji stanąć przed groźbą poważnych strat nie tylko w aspekcie politycznym, lecz także gospodarczym, szybko okazało się, że nie będą one bardzo dotkliwe, gdyż postawy poszczególnych państw Zachodu stawały się wraz z upływem czasu coraz bardziej zróżnicowane. Przykładowo konsternacja, jaka zapanowała w Australii na wieść o wydarzeniach w Pekinie i związane z tym oczekiwanie respektowania praw

${ }^{101}$ Ibidem, Notatka dotycząca oceny sytuacji w Chinach po IV Plenum KC KPCh, 26 VIII 1989 r., k. nlb.

${ }^{102}$ Ibidem, Notatka informacyjna nt. kryzysu politycznego w Chinach opracowana przez Ksawerego Burskiego, 12 VI 1989 r., k. nlb.

${ }^{103}$ Ibidem, Wstępna ocena wydarzeń w Pekinie (kwiecień-czerwiec 1989) sporządzona przez ambasadora PRL w Pekinie Mariana Woźniaka, 26 VI 1989 r., k. nlb. W NRD pacyfikację protestów odebrano jako stłumienie „kontrrewolucji”, co miało duże znaczenie, gdyż kwestia użycia siły przeciwko buntownikom do pewnego momentu była przez Ericha Honeckera uznawana za sprawę otwarta. Zob. A. Gubrynowicz, NRD - przegrana rewolucja?, w: A. Burakowski, A. Gubrynowicz, P. Ukielski, 1989 - Jesień Narodów, Warszawa 2009, s. 127. 
człowieka, wyrażone przez premiera Boba Hawke’a (wzią on udział w nabożeństwie upamiętniającym ofiary oraz obiecał nadanie studentom chińskim przebywającym w jego kraju obywatelstwa Australii), nie przeszkodziły w ostatecznym dojściu do wniosku, że izolacja ChRL nie leży w interesie Canberry ${ }^{104}$.

Obserwując to, Burski oceniał, iż do wprowadzenia sankcji wobec ChRL, jak miało to miejsce w przypadku PRL po 13 XII 1981 r., nie dojdzie z dwóch powodów. Pierwszy odnosił się do tego, że ponowna izolacja lub samoizolacja Chin będzie niekorzystna dla wszystkich państw utrzymujących z nimi silne relacje gospodarcze. Drugi zaś to fakt, iż Zachód nie interesował się popchnięciem Pekinu w objęcia Moskwy, co mogło nastapić w rezultacie jednostronnego odejścia od uczestnictwa w polityce „otwarcia”. Zwracano w tym kontekście uwagę m.in. na bardzo ostrożne wypowiedzi prezydenta Stanów Zjednoczonych George'a Busha, pomimo silnych nacisków wywieranych w Kongresie na zdecydowane działania ${ }^{105}$. Ostatecznie Stany Zjednoczone wprowadziły sankcje, ale tylko na transakcje o charakterze wojskowym, Szwecja zablokowała kredyty dla Chin, niemniej jednak ostrość reakcji zależała od stopnia powiazań gospodarczych. Burski oceniał, iż może nastapić przejściowe zachwianie współpracy między Zachodem a ChRL, której wznowienie będzie uzależnione od legalizacji opozycji i dalszych reform ${ }^{106}$. Jednakże już niecałe dwa miesiące po krwawej pacyfikacji demonstracji w Pekinie polscy dyplomaci stwierdzili, że po pierwszym szoku i krótkim okresie izolacji można było obserwować powolny renesans w stosunkach między ChRL a jej zachodnimi partnerami, na co wpływała także duża aktywność chińskiej dyplomacji. Zwracano też uwagę, podobnie jak uczynił to wcześniej Burski, że sankcje wobec Pekinu były łagodniejsze od tych, jakie zastosowano wobec Warszawy w związku $\mathrm{z}$ wprowadzeniem stanu wojennego $\mathrm{w}$ PRL ${ }^{107}$, co wiele mówiło o prawdziwych priorytetach państw zachodnich, oficjalnie potępiających komunistów chińskich za czerwcową masakrę w stolicy Chin ${ }^{108}$.

${ }^{104}$ M. Sprengel, Znaczenie politycznych i gospodarczych relacji Australii $z$ Japonia $i$ Chinami w latach 1970-2000, „Krakowskie Studia Międzynarodowe” 2009, nr 1 (6), s. 117-118.

105 Zob. też: M. Grabowski, op. cit., s. 115.

${ }^{106}$ AMSZ, Departament II, z. 4/94, w. I, Notatka informacyjna nt. kryzysu politycznego w Chinach opracowana przez Ksawerego Burskiego, 12 VI 1989 r., k. nlb.

107 Ibidem, Notatka dotyczaca oceny sytuacji w Chinach po IV Plenum KC KPCh, 26 VIII 1989 r., k. nlb.

${ }^{108} \mathrm{~W}$ charakterystyczny sposób podszedł do sprawy oceny wydarzeń w ChRL Gorbaczow: „Politycy muszą być ostrożni w tych sprawach [ocenie wydarzeń]. Zwłaszcza, jeśli mówimy o takim kraju, jak Chiny. Z krajem o populacji powyżej miliarda ludzi. To jest cała cywilizacja! [...] Nie usprawiedliwiamy niczego, ale w tym samym czasie musimy pokazać naszą troskę poprzez [nasze] oceny sytuacji. Poza tym nigdy nie będziemy wiedzieć ilu ludzi tam zginęło. Brak jakichkolwiek rozsądnych danych na ten temat i prawdopodobnie nigdy się one nie pojawią. [...] Myślę, że z naszej strony powinniśmy prezentować bardzo ostrożne podejście do chińskich przywódców. Potrzebują czasu, by zorientować się w sytuacji. [...] Studenci przysłali mi bardzo ciepły list. Można im współczuć, jako człowiek; można 
Wydaje się, iż można w tym kontekście doszukiwać się pewnych analogii np. do wydarzeń z 1956 r. na Węgrzech, podczas których Waszyngton udzielał znacznego wsparcia werbalnego tamtejszej opozycji antykomunistycznej, jednakże nie uczynił nic, by zapobiec jej brutalnemu zdławieniu przez wojska sowieckie. Pekińscy demonstranci mogli liczyć na potężne wsparcie moralne ze strony Zachodu, śledzącego kolejne fazy kryzysu, jednak ostatecznie okazało się, że Deng Xiaoping miał bardzo dużo racji, gdy dwa lata wcześniej prognozował, że powiązania ekonomiczne będą ważniejsze od praw człowieka. Stany Zjednoczone mogły nałożyć sankcje na średniej wielkości państwa europejskie o słabej gospodarce, jak PRL, lecz nie pozwoliły sobie na takie postępowanie w przypadku tak ważnego uczestnika stosunków międzynarodowych, jak ChRL, mimo że w nocy z 3 na 4 VI 1989 r. na skutek bezpośredniego działania władz zginęło o wiele więcej ludzi, aniżeli przez cały stan wojenny w Polsce.

\section{Zakończenie}

Brutalny pokaz siły i determinacji KPCh wobec swego społeczeństwa w kontekście zwalczania wszelkich przejawów działalności wymierzonej w politykę rządu okazał się, abstrahując od jego jednoznacznie negatywnej oceny moralnej, skutecznym posunięciem. Rosnący w siłę pod koniec lat osiemdziesiątych ruch studencki, którego postulaty, jak pokazały wydarzenia z pierwszej połowy 1989 r., zmierzały ku demokratyzacji ChRL, został skutecznie spacyfikowany. Wprawdzie Uniwersytet Pekiński działalność dydaktyczna podją dopiero 14 października (jako ostatnia wyższa uczelnia), lecz sytuacja, pomimo pewnych obaw ze strony władz, pozostała pod kontrola, czego najlepszym dowodem okazał się spokojny przebieg 40. rocznicy utworzenia ChRL 21 IX 1989 r. ${ }^{109} \mathrm{~W}$ Szanghaju, gdzie zastosowano nieco inne metody niż w Pekinie, także udało się osiagnąć uspokojenie nastrojów. Jak pisał attaché konsularny tamtejszego Konsulatu Generalnego PRL, Frydrych:

Podobno w Szanghaju istnieje 80 różnych nielegalnych organizacji, ale nic dokładnie nie wiadomo o ich sile i wpływie. Władze roztoczyły ścisłą kontrolę nad studentami, kontrolując ich poczynania. Realną siłą polityczną są robotnicy przemysłowi. Ale władze poważnie traktują tę grupę, unikając jakichkolwiek decyzji raptownych, które mogłyby naruszać interesy robotników wielkich i średnich zakładów państwowych. Mimo narastającego niezadowolenia różnych grup społecznych i spadku prestiżu partii w społeczeństwie, nie widać żadnych poważnych sił, które realnie naruszył[y]by spokój

żałować co się stało. To jest oczywiście tragedia. Powinniśmy jednak analizować głębokie przyczyny [obecnej] sytuacji”. Wilson Center Digital Archive, Excerpts from the conversation between Mikhail Gorbachev and Rajiv Gandhi, 15 VII 1989 r. (dostęp: 19 V 2019).

109 AMSZ, Departament II, z. 4/94, w. I, Notatka dotycząca oceny sytuacji w Chinach po IV Plenum KC KPCh, 26 VIII 1989 r., k. nlb. 
społeczny wystapieniami na miarę kwietnia-czerwca (chyba, że nastapi załamanie gospodarcze). Rozwój sytuacji społeczno-politycznej determinować będzie przebieg walki w kierownictwie centralnym i ewentualnie oddźwięk tej walki na prowincji ${ }^{110}$.

Potężnemu „kijowi” w postaci użycia wojska przeciwko obywatelom towarzyszyła „marchewka” w postaci nowego, relatywnie młodego sekretarza generalnego KPCh, który mógł symbolizować lepsze nadzieje na przyszłość, związane przede wszystkim z poprawą sytuacji gospodarczej. Deng Xiaoping chociaż lokował swe sympatie raczej po stronie „konserwatystów” aniżeli „liberałów”, nie dopuścił, by ci pierwsi nadmiernie wzmocnili swe wpływy po czerwcu i zawrócili ChRL z drogi reform obranej w 1978 r., która była przecież także, a może przede wszystkim, drogą Deng Xiaopinga i jego największym osiagnięciem. Wbrew obawom niektórych obserwatorów nie doszło np. do wzmocnienia pozycji armii. Deng Xiaoping wskazywał na preferowana przez siebie i realizowana po $1989 \mathrm{r}$. dwutorową koncepcję rozwoju sytuacji w ChRL, np. 20 VIII 1991 r.: „Musimy nadal podkreślać potrzebę walki z burżuazyjna liberalizacją realizując politykę reform i otwarcia oraz przesuwając punkt ciężkości naszej pracy na rozwój gospodarczy. Nie wyrzekniemy się idei Marksa, Lenina i Mao Zedonga. Nie możemy zapomnieć o naszych przodkach!"111.

Wprawdzie społeczeństwo ChRL zapłaciło za to wielką cenę, niemniej kryzys systemu politycznego w 1989 r., w przeciwieństwie do wielu państw komunistycznych, z ZSRS na czele, został jednak opanowany, a Pekin jest obecnie jednym z najważniejszych elementów międzynarodowych stosunków politycznych i gospodarczych, gdy „zreformowany” przez Gorbaczowa ZSRS zakończył swój żywot w $1991 \mathrm{r}$.

Oczywiście, obecne Chiny sa inne od tych z 1989 r., jednak trudno ocenić, jak potoczyłyby się losy tego państwa, gdyby KPCh realizowała do końca politykę wytyczona przez Zhao Ziyanga. Nie można wykluczyć, że - nieprzygotowane na szybkie i daleko idące zmiany, przy zachowaniu silnej pozycji wrogich im „konserwatystów”, kontrolujacych resorty siłowe - popadłoby $\mathrm{w}$ chaos, o ile nie doszłoby wcześniej do zbrojnego zamachu stanu ze strony „sił reakcyjnych”. Wszak nawet po relatywnie pomyślnym z ich punktu widzenia rozwiązaniu sprawy „kontrrewolucji” w czerwcu 1989 r., zaczynały już one gdzieniegdzie „podnosić głowę”, pozwalając sobie nawet na krytykę XIII Zjazdu KPCh z 1978 r. (a więc i samego Deng Xiaopinga) jako źródła problemów. Trudno też odpowiedzieć, jak duże poparcie uzyskałyby ostatecznie postulaty demonstrantów, a zwłaszcza ludności wiejskiej. Jednocześnie

${ }^{110}$ Ibidem, Ocena sytuacji polityczno-społecznej i gospodarczej przygotowana przez attaché konsularnego Konsulatu Generalnego PRL w Szanghaju Marka Frydrycha, 27 IX 1989 r., k. nlb.

111 „Analizujcie wasze doświadczenia i korzystajcie z usług wyszkolonych profesjonalistów” (fragment rozmowy z członkami kierownictwa Komitetu Centralnego KPCh), 20 VIII 1991, w: Koncepcje nauki..., s. 211-212. 
być może udałoby się wówczas skierować ChRL w sposób pokojowy na drogę szybszej ewolucji w kierunku państwa o bardziej demokratycznym ustroju, którego elitą staliby się z czasem pełni ideałów studenci rozjechani przez czołgi w nocy z 3 na 4 czerwca bądź też ci zmuszeni do emigracji lub straceni, albo osadzeni w więzieniach na skutek późniejszych represji ze strony władz. Są to wprawdzie wyłącznie przypuszczenia, z którymi można polemizować, niemniej warto się nad nimi zastanowić.

\section{Streszczenie}

Celem artykułu jest zaprezentowanie genezy, przebiegu i konsekwencji tzw. wydarzeń kwietniowo-czerwcowych z 1989 r. w Chińskiej Republice Ludowej. ChRL, kierowana w 1989 r. przez Deng Xiaopinga, przeszła przez poważny kryzysy wewnętrzny, który skutkował masowymi protestami studenckimi w Pekinie (m.in. na pl. Tiananmen) i innych dużych miastach. Niepokoje społeczne początkowo miały głównie ekonomiczne podłoże, niemniej w krótkim czasie demonstranci zaczęli wysuwać także żądana polityczne. Do eskalacji protestu doszło w drugiej połowie maja, co wiązało się z przyjazdem do Pekinu Michaiła Gorbaczowa. Punktem kulminacyjnym był protest głodowy na pl. Tiananmen. W rezultacie grupa wpływowych komunistycznych liderów przeciwstawiajacych się jakimkolwiek formom politycznej liberalizacji w ChRL przekonała Deng Xiaopinga, że demonstrujący studenci stanowią realne zagrożenie dla istnienia systemu komunistycznego w Chinach. Gdy podjęte próby dialogu rządu z protestującymi zakończyły się fiaskiem, a studenci zyskali silne poparcie ze strony mieszkańców Pekinu, Deng Xiaoping podjął pod koniec maja decyzję o wprowadzeniu stanu wyjątkowego oraz siłowym rozwiąaniu problemu. Brutalne stłumienie demonstracji przez wojsko na początku czerwca skończyło się masakrą na ulicach Pekinu (liczba ofiar nie została dotąd precyzyjnie ustalona). Kryzys zakończył się politycznym upadkiem sekretarza generalnego Komunistycznej Partii Chin Zhao Ziyanga (okazał się nazbyt „liberalny”), którego zastapił Jiang Zemin, kontynuujący tzw. politykę otwarcia i reform na warunkach Deng Xiaopinga.

\section{"A Storm over Beijing". The Causes, Course, and Consequences of the Crisis in the People's Republic of China in 1989 in the Light of Archives of the Polish People's Republic}

The purpose of the article is to present the genesis, course and consequences of the so-called 1989 April-June incidents that took place in the People's Republic of China. The PRC, in 1989 under the strong leadership of Deng Xiaoping, underwent a series of internal crises that led to massive students demonstrations in Beijing (mainly at Tiananmen Square) and other large cities. In the beginning, social unrest was caused mostly by economic reasons, but in short time demonstrators also introduced political demands. The protest escalated in the second half of May, as a result of Mikhail Gorbachev visit to Beijing. The culminating point of the protests was the hunger strike at Tiananmen Square during the Gorbachev's visit. As a result, a group of influential Chinese communist leaders opposed to any form of political liberalisation in China convinced Deng Xiaoping that demonstrating students posed a real threat to the very existence of the communist movement in the Republic. When all attempts at a dialogue between the government and protesters failed, and students gained severe support of the Beijing inhabitants, at the end of May Deng Xiaoping decided to impose martial law and resolve the problem by brute force. The brutal military suppression of demonstrations undertaken in the early June resulted in a massacre on the streets of 
Beijing (the total number of casualties to this day has not been precisely established). The crisis ended with the political downfall of the China Communist Party's General Secretary Zhao Ziyang (too "liberal"), replaced by Jiang Zemin who continued the so-called "policy of openness" and reforms on Deng Xiaoping's terms.

\section{Bibliografia}

Brook T., Quelling the People. The Military Suppression of the Beijing Democracy Movement, Stanford 1998.

Cheng E., Standoff at Tiananmen, Highlands Ranch 2009.

Chiny rok po Tiananmen, Warszawa 1990.

Culture and Politics in China. An Anatomy of Tiananmen Square, red. P. Li, M.H. Li, S. Mark, New Brunswick 1991.

Francis C.B., The Progress of Protest in China: The Spring of 1989, „Asian Survey” 1989, nr 9. Gacek Ł., Chińskie elity polityczne w XX wieku, Kraków 2009.

Gawlikowski K., Bogdan Góralczyk, Pekińska wiosna 1989. Poczatki ruchu demokratycznego $w$ Chinach, Warszawa 1999, Studio Wydawnicze Familia, ss. 261 [rec.], „Dzieje Najnowsze" 2000, nr 1.

Gołojuch G., Cztery pokolenia chińskich przywódców. Problemy lub przebieg instytucjonalizacji sukcesji wtadzy w Chinskiej Republice Ludowej, „Politeja” 2005, nr 1 (3).

Góralczyk B., Pekińska wiosna 1989. Poczqtki ruchu demokratycznego w Chinach, Warszawa 1999.

Grabowski M., Wiek Pacyfiku - polityka Stanów Zjednoczonych wobec regionu Azji i Pacyfiku po roku 1989, Kraków 2012.

Gubrynowicz A., NRD - przegrana rewolucja?, w: A. Burakowski, A. Gubrynowicz, P. Ukielski, 1989 - Jesień Narodów, Warszawa 2009, s. 101-182.

Koncepcje nauki, szkoły i wychowania w ujęciu Deng Xiaopinga. Fragmenty przemówień z lat 1938-1992, wybór, tłum. i oprac. J. Marszałek-Kawa, Toruń 2013.

Liu A.P.L., Aspects of Beijing's Crisis Management: The Tiananmen Square Demonstration, „Asian Survey” 1989, nr 5.

Łoziński K., Piekło Środka. Chiny a prawa człowieka, Warszawa 1996.

Naughton B., The Impact of the Tiananmen Crisis on China's economic transition, w: The Impact of China's 1989 Tiananmen Massacre, red. J.P. Béja, New York 2011, s. 63-78.

Polit J., Chiny, Warszawa 2004.

Prisoner of the State. The Secret Journal of Premier Zhao Ziyang, New York 2009.

Sprengel M., Znaczenie politycznych $i$ gospodarczych relacji Australii $z$ Japonia $i$ Chinami w latach 1970-2000, „Krakowskie Studia Międzynarodowe” 2009, nr 1 (6).

Vogel E.F., Deng Xiaoping and the Transformation of China, Cambridge-London 2011.

Willbanks J.H., Fang Lizhi's Expanding Universe, „The China Quarterly” 1990, nr 9 (123).

Zhao D., The Power of Tiananmen. State-Society Relations and the 1989 Beijing Student Movement, Chicago-London 2001.

Biog r a m: Przemysław Benken - dr; historyk i politolog, pracownik Oddziałowego Biura Badań Historycznych Instytutu Pamięci Narodowej w Szczecinie. Autor wielu publikacji naukowych z zakresu historii wojskowej XIX-XX w., historii politycznej Azji w XX w. oraz historii Polski po 1945 r., m.in. Ofensywa Tet 1968. Studium militarno-polityczne (Szczecin 2014); Hamburger Hill 1969 (Warszawa 2016); Tajemnica śmierci Jana Rodowicza „Anody” (Warszawa 2016). E-m ail: przemyslaw.benken@ipn.gov.pl. 